\title{
Mechanical Properties and Microstructure of Low Carbon Binders Manufactured from Calcined Canal Sediments and Ground Granulated Blast Furnace Slag (GGBS)
}

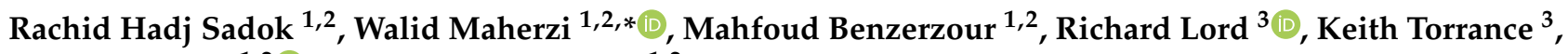 \\ Agnes Zambon ${ }^{1,2}$ and Nor-Edine Abriak ${ }^{1,2}$ \\ 1 Center of Materials and Processes, Institut Mines-Télécom, IMT Lille Douai, 59000 Lille, France; \\ rachid.hadj-sadok@imt-lille-douai.fr or rachid.hadjsadok@univ-mosta.dz (R.H.S.); \\ mahfoud.benzerzour@imt-lille-douai.fr (M.B.); agnes.zambon@imt-lille-douai.fr (A.Z.); \\ nor-edine.abriak@imt-lille-douai.fr (N.-E.A.) \\ 2 LGCgE-GCE, IMT Lille-Douai, 941 Rue Charles Bourseul, 59500 Douai, France \\ 3 Department of Civil and Environmental Engineering, University of Strathclyde, 75 Montrose Street, \\ Glasgow G1 1XJ, UK; richard.lord@strath.ac.uk (R.L.); keith.w.torrance@strath.ac.uk (K.T.) \\ * Correspondence: walid.maherzi@imt-lille-douai.fr
}

Citation: Hadj Sadok, R.; Maherzi, W.; Benzerzour, M.; Lord, R.; Torrance, K.; Zambon, A.; Abriak, N.-E. Mechanical Properties and Microstructure of Low Carbon Binders Manufactured from Calcined Canal Sediments and Ground Granulated Blast Furnace Slag (GGBS). Sustainability 2021, 13, 9057. https://doi.org/10.3390/su13169057

Academic Editor: José

Ignacio Alvarez

Received: 6 July 2021

Accepted: 9 August 2021

Published: 12 August 2021

Publisher's Note: MDPI stays neutral with regard to jurisdictional claims in published maps and institutional affiliations.

Copyright: (c) 2021 by the authors. Licensee MDPI, Basel, Switzerland. This article is an open access article distributed under the terms and conditions of the Creative Commons Attribution (CC BY) license (https:/ / creativecommons.org/licenses/by/ $4.0 /)$.

\begin{abstract}
This research study evaluated the effects of adding Scottish canal sediment after calcination at $750{ }^{\circ} \mathrm{C}$ in combination with GGBS on hydration, strength and microstructural properties in ternary cement mixtures in order to reduce their carbon footprint $\left(\mathrm{CO}_{2}\right)$ and cost. A series of physicochemical, hydration heat, mechanic performance, mercury porosity and microstructure tests or observations was performed in order to evaluate the fresh and hardened properties. The physical and chemical characterisation of the calcined sediments revealed good pozzolanic properties that could be valorised as a potential co-product in the cement industry. The results obtained for mortars with various percentages of calcined sediment confirmed that this represents a previously unrecognised potential source of high reactivity pozzolanic materials. The evolution of the compressive strength for the different types of mortars based on the partial substitution of cement by slag and calcined sediments showed a linear increase in compressive strength for 90 days. The best compressive strengths and porosity were observed in mortars composed of 50\% cement, $40 \%$ slag and $10 \%$ calcined sediment (CSS10\%) after 90 days. In conclusion, the addition of calcined canal sediments as an artificial pozzolanic material could improve strength and save significant amounts of energy or greenhouse gas emissions, while potentially contributing to Scotland's ambitious 2045 net zero target and reducing greenhouse gas emissions by 2050 in the UK and Europe.
\end{abstract}

Keywords: calcined canal sediment; slag; characterisation; ternary cement; circular economy; greenhouse gas emissions; eco-friendly binders

\section{Introduction}

In recent years, the utilisation of supplementary cementitious materials in the building sector [1] as an alternative material has been considered as a suitable solution for improving sustainability [2]. The consumption of cement in Great Britain increased considerably between 2014 and 2019 from around 12.4 million metric tons to approximately 15.2 million metric tons in 2019, which represents a significant environmental impact and cost [3]. Indeed, cement factories are considered extremely polluting (emitting roughly $1 \mathrm{t} \mathrm{CO}_{2}$ for every $1 \mathrm{t}$ clinker) [4], with consumption of natural resources and energy (8000 J for every $1 \mathrm{t}$ clinker) that are relatively costly (200€ for every $1 \mathrm{t}$ clinker). To this end, several current studies are aimed at finding new solutions in order to reduce the impact of construction, in general, on the environment and the ecosystem.

Blast furnace slag and dredged sediments can be used as partial replacements of cement $[5,6]$. The valorisation of treated sediments in the building sector is a credible 
alternative opportunity that has been examined by many authors [7-9]. The blast furnace slag is also widely used as an alternative material in cement manufacturing for reducing greenhouse gas emissions [10]. It is considered as a by-product and has been used to reduce the environmental impact and economic cost. In addition, the heating effects of the hydration of cement are reduced with partial replacement by slag and the durability of concrete increased while the workability improved [11,12]. At early maturation ages, the slag addition decreases the strength due to the slower chemical hydration heat reactions, with the high rate of substitution [13]. Recently, Deboucha et al. [14] studied the combined effect of limestone filler and slag on the hydration heat. The results of this study have confirmed that the hydration heat and compressive strength depends on the content and water $/$ binder $(\mathrm{w} / \mathrm{b}$ ratio) of limestone filler and slag in proportion to the degree of reaction.

Dredged sediments are one of the largest potential waste streams in the EU, with an annual production of about 50 million in France and 300 million tons in Europe [15], which could potentially contribute to the UK and Europe's ambitious 2050 net zero target. Nowadays, the removal of dredged sediment has become a significant environmental and economic issue because of their common excessive content of potentially toxic elements such as $\mathrm{As}, \mathrm{Cd}, \mathrm{Pb}, \mathrm{Cr}, \mathrm{Cu}, \mathrm{Ni}, \mathrm{Hg}$ and $\mathrm{Zn}$; organic matter (humic and fulvic acids); and likely salinity [16]. The use of dredged sediments as a substitution of granular compounds or the mineral addition of cement was recommended $[7,17,18]$. Their utilisation can positively affect the properties of fresh $[18,19]$ and hardened concrete $[20,21]$. Several studies have shown that the calcination of sediments between $650{ }^{\circ} \mathrm{C}$ and $850{ }^{\circ} \mathrm{C}$ can provide many advantages when employed in mortar and concrete formulation. Dang et al. [7] have analysed the impact of calcined sediment in concrete. They have indicated that the incorporation of calcined sediment in cementitious matrices improves the compressive strength compared to a classical calcareous filler. This was explained by the fact that the clay minerals present in the sediment are activated at $650{ }^{\circ} \mathrm{C}$ [22].

Furthermore, numerous parameters such as fineness, heat treatment temperature and setting time affect the performance and pozzolanic activity [23,24]. As per Dodson [25], when a pozzolan is available in a cement matrix, this allows consumption of residual calcium hydroxide. This creates new hydration phases, such as calcium-silica-hydrate (CSH), that improve the mechanical strength of the cementitious matrices. Moreover, sediments are heterogeneous materials that are characterised by a high water demand, which is caused by the presence of organic matter and clay phases. These latter components are especially common in canal sediments, such as those in Scotland, and can affect the cementitious material matrix when utilized as a mineral admixture. A few investigations and research studies have demonstrated the viability of utilizing dredged sediment in the building sector as a partial replacement for fine aggregate or cement $[6,26,27]$ with the objective of improved environmental performance. Moreover, the level of hydration in cementitious material increased in the presence of finely crushed admixture due to the improved hydration of cement $[28,29]$. Thus, the valorisation of treated sediments in the building sector is a credible opportunity that is examined by many authors [7-9].

Over the last few years, numerous studies have explored the reuse of sediment and blast furnace slag as secondary raw materials for different applications: as lightweight aggregate [30], as brick and tiles [31], as a backfilling for road construction [32] or as mineral additions for cement and geopolymer. In this paper, we study the potential reuse of calcined freshwater canal sediment and GGBS on ternary cement mixture properties. Moreover, the mechanical strength performance and microstructure of binders were investigated.

\section{Materials and Methods}

Formulations of sand and cement with additions of either slag or slag/sediment mixtures at up to $20 \mathrm{wt} \%$ of treated sediment were tested, with each of them evaluated regarding the properties of the fresh pastes and hardened states of mortar mixtures. The crystalline phases were identified by using $\mathrm{X}$-ray diffraction (XRD). Thermogravimetric analysis (TGA) of the hardened pastes was used to determine the continent of $\mathrm{Ca}(\mathrm{OH})_{2}$. 
The microstructural proprieties of hardened mortar were also investigated by using electron microscopy (SEM).

\subsection{Materials}

- Sediments

The sediment used in this study was supplied by the Scottish Canal, which is the organisation that manages Scotland's waterways and is responsible for dredging to maintain a statutory navigational draught. The sediment treated by calcination (CS) was collected from Laggan on the Caledonian Canal as part of the SURICATES Interreg NWE Project 462 [33]. The sediments at Laggan are slightly clayey silty sands or sandy silts, which are becoming gravelly close to the input point of an upland feeder stream. Loss upon ignition at $550{ }^{\circ} \mathrm{C}$ ranges from $10-18 \%$ reflect their moderate organic matter content compared to other Scottish canal sediments. The untreated sediment (RS) was homogenized, and all residual plant materials were removed by sieving samples at $5 \mathrm{~mm}$. It was next dried at $40{ }^{\circ} \mathrm{C}$ then grounded to $<120 \mu \mathrm{m}$. After that the sediment was calcined by using direct calcination at $750{ }^{\circ} \mathrm{C}[34,35]$. The chemical and mineralogical characteristics for these materials are shown in Tables 1 and 2, respectively.

Table 1. Oxide composition of cement, slag, raw and calcined sediment using XRF (weight \%).

\begin{tabular}{|c|c|c|c|c|}
\hline Oxides Composition & CEM I $42.5 \mathrm{R}$ & Slag & Raw Sediment & Calcined Sediment \\
\hline $\mathrm{SiO}_{2}$ & 17.33 & 32.30 & 58.19 & 57.33 \\
\hline $\mathrm{Al}_{2} \mathrm{O}_{3}$ & 4.72 & 11.34 & 17.19 & 19.46 \\
\hline $\mathrm{Fe}_{2} \mathrm{O}_{3}$ & 2.72 & 0.43 & 6.05 & 6.43 \\
\hline $\mathrm{CaO}$ & 60.73 & 39.74 & 1.26 & 1.12 \\
\hline $\mathrm{Na}_{2} \mathrm{O}$ & 0.27 & 0.27 & 2.29 & 2.43 \\
\hline $\mathrm{K}_{2} \mathrm{O}$ & 0.96 & 0.48 & 3.73 & 4.10 \\
\hline $\mathrm{P}_{2} \mathrm{O}_{5}$ & 0.23 & 0 & 0.46 & 0.46 \\
\hline $\mathrm{SO}_{3}$ & 4.25 & 1.75 & 0.5 & 0.25 \\
\hline $\mathrm{TiO}_{2}$ & 0.33 & 0.67 & 1 & 1 \\
\hline
\end{tabular}

Table 2. Physical characterisation of materials.

\begin{tabular}{cccc}
\hline Parameters & Cement & Slag & Calcined Sediment \\
\hline Density $\left(\mathbf{g} / \mathrm{cm}^{3}\right)$ & 3.15 & 2.92 & 2.78 \\
BET $\left(\mathbf{c m}^{\mathbf{2}} / \mathbf{g}\right)$ & 9194 & 16,102 & 59,930 \\
Fineness $\left(\mathrm{cm}^{2} / \mathbf{g}\right)$ & 3485.65 & 4233.53 & 6194.90 \\
Water demand $(\%)$ & 30.5 & 34 & 40 \\
pH & 12.76 & 10.07 & 8.10 \\
\hline
\end{tabular}

\section{- Cement}

The proposed mortars were formulated with Portland cement (CEM I 42.5R) in compliance with European standard EN 197-1 (2012) [36]. The characteristics for this cement are presented in Table 1. Particle size distributions for the materials used are illustrated in Figure 1. This cement was composed of over $95 \%$ clinker and less than 5\% secondary components. It had an initial setting time of more than $45 \mathrm{~min}$. After 28 days, the simple compression strength, according to EN 196-1 [37], was greater than $42.5 \mathrm{MPa}$. 


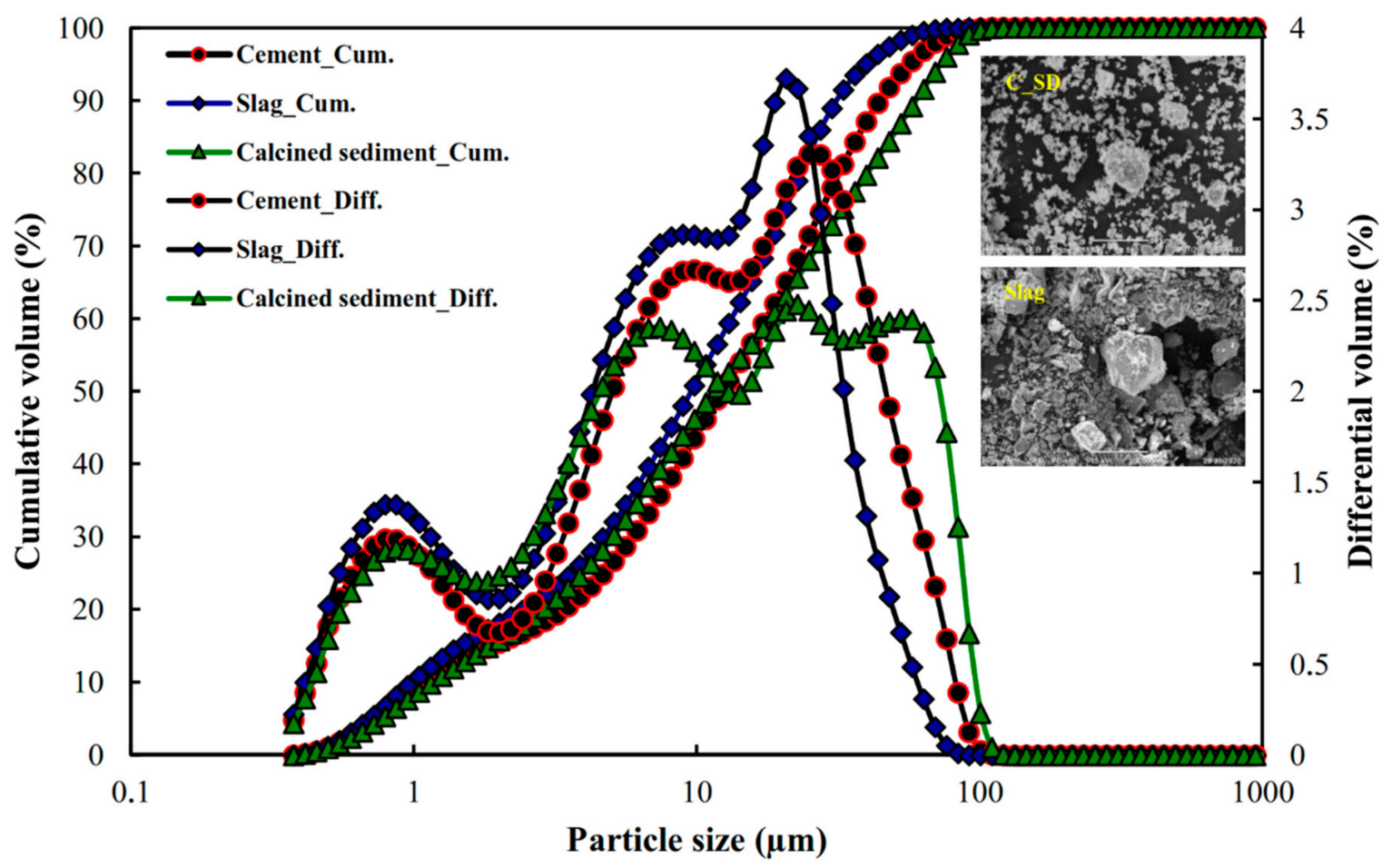

Figure 1. Particle size distribution of calcined sediment (CS), blast furnace slag (S) and cement (C).

Table 2 illustrates the physical characterization of the materials used. The cement possessing the highest density is at $3.15 \mathrm{~g} / \mathrm{cm}^{3}$, followed by the blast furnace slag of 2.92, and the calcined sediment at 2.78. Calcined sediments were found to have the highest specific surface area $\left(6194.90 \mathrm{~cm}^{2} / \mathrm{g}\right)$ and water demand $(40 \%)$ [38].

Table 3 summarises the results of the major and trace element analysis of the materials used by X-ray Fluorescence (XRF). It has shown that the calcined sediments are enriched in silicon (26.8\%), aluminium (10.3), iron (4.5\%), potassium $(3.4 \%)$ and sodium $(1.8 \%)$ compared to the other ingredients, but contain less calcium $(0.8 \%)$ and sulphur $(0.1 \%)$.

Table 3. Chemical composition of materials used.

\begin{tabular}{ccccccccccccc}
\hline Element & Al & Ca & Fe & K & Mg & Mn & Na & O & P & S & Si & Ti \\
\hline Cement & 2.5 & 43.4 & 2.8 & 0.8 & 0.4 & - & 0.2 & 40.5 & 0.1 & 1.7 & 8.1 & 0.2 \\
Slag & 6.0 & 28.4 & 0.3 & 0.4 & 3.8 & 0.1 & 0.2 & 44.4 & 0.18 & 0.7 & 15.1 & 0.4 \\
Raw sediment & 9.1 & 0.9 & 4.7 & 3.1 & 1.1 & - & 1.7 & 50.7 & 0.2 & 0.2 & 27.2 & 0.6 \\
Calcined sediment & 10.3 & 0.8 & 4.5 & 3.4 & 1.1 & - & 1.8 & 50.0 & 0.2 & 0.1 & 26.8 & 0.6 \\
\hline
\end{tabular}

The results obtained by the granulometry test performed by using a BEKMANCOULTER LS13320 on these materials are presented in Figure 1 and Table 4. The laser granulometry analysis determines the granular particle distribution under $2 \mathrm{~mm}$. The samples were also set to dry analysis. The particle size distribution of slag indicated a more significant percentage of fine particles compared to the calcined sediment (CS) and cement (C). For example, $90 \%$ of the slag particles were less than $31.3 \mu \mathrm{m}$ compared to $59.70 \mu \mathrm{m}$ for calcined sediment and $44.46 \mu \mathrm{m}$ for cement. 
Table 4. Cumulative volume of particle size.

\begin{tabular}{cccc}
\hline Particle Diameter $<(\mu \mathrm{m})$ & Cement & Slag & Calcined Sediment \\
\hline D 10 & 1.11 & 0.99 & 1.17 \\
D 25 & 4.71 & 3.63 & 3.98 \\
D 50 & 12.37 & 9.58 & 11.58 \\
D 75 & 27.65 & 20.61 & 32.82 \\
D 90 & 44.46 & 31.31 & 59.70 \\
\hline
\end{tabular}

Table 3 summarises the results of the major and trace element analysis of the materials used by X-ray Fluorescence (XRF). It was observed that the calcined sediments are enriched in silicon $(26.8 \%)$, aluminium $(10.3)$, iron $(4.5 \%)$, potassium $(3.4 \%)$ and sodium $(1.8 \%)$ compared to the other ingredients but contain less calcium $(0.8 \%)$ and sulphur $(0.1 \%)$.

Figure 2 shows scanning electron microscope (SEM) observations images of slag and calcined sediments at the same magnification. Calcined sediment is made up of irregular particles with highly variable particles size from $1.17 \mu \mathrm{m}$ to $59.70 \mu \mathrm{m}$. Slag is composed of fine particles size from $0.99 \mu \mathrm{m}$ to $31.31 \mu \mathrm{m}$.

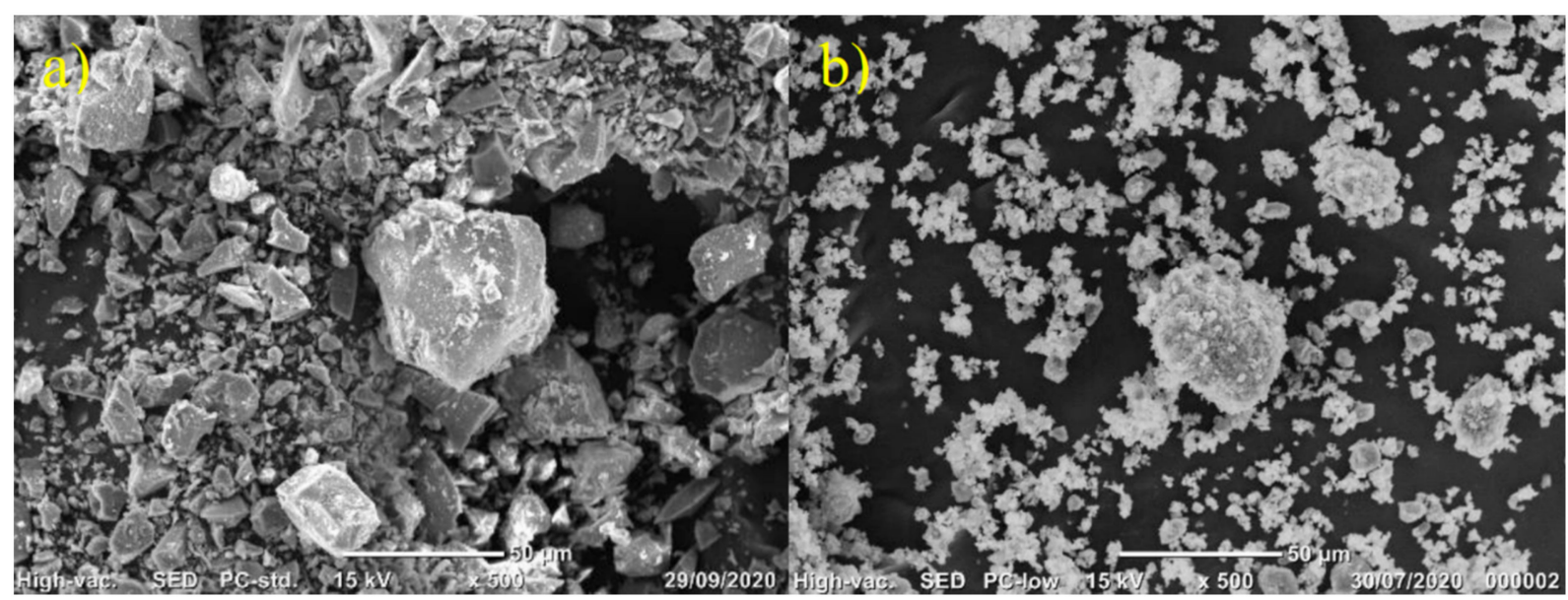

Figure 2. Particle morphology: (a) slag (S); (b) calcined sediment (CS).

Figure 3 shows XRD diffractograms of the sediment before and after calcination. It has been used to determine the qualitative mineral composition and some crystalline minerals and amorphous phases of the tested samples. It indicates that the samples are rich in quartz, albite, illite and muscovite, which is consistent with the range of igneous, metamorphic and sandstone-dominant sedimentary rocks in the sediment source area. Both samples are broadly similar, with the exception of the appearance of traces of metakaoline in the sediment after calcination at $750{ }^{\circ} \mathrm{C}$. 


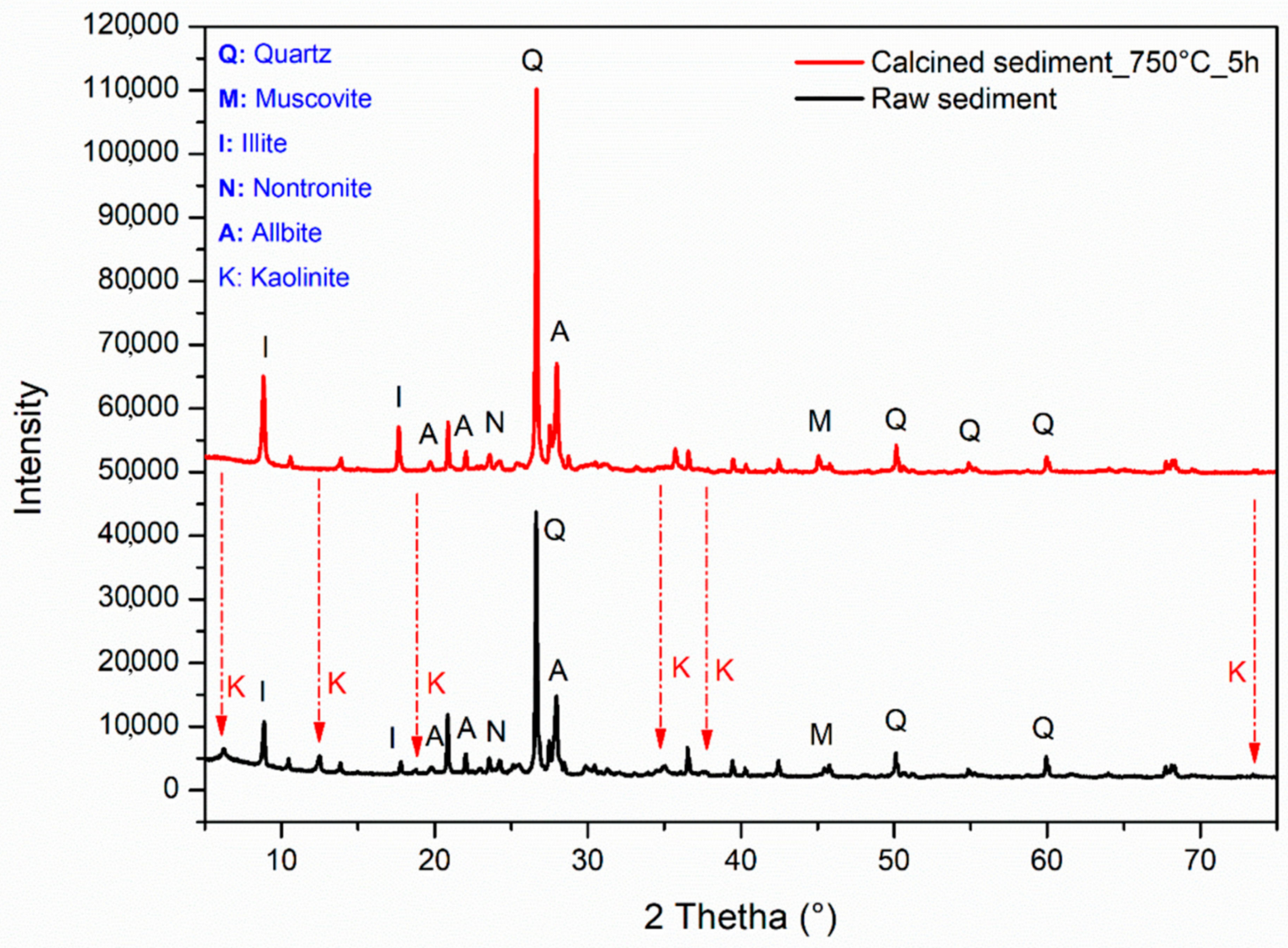

Figure 3. XRD mineralogical analysis of raw sediment and calcined sediment.

\subsection{Preparation of Mortar Mixtures}

Several mortar formulations were prepared using Portland cement CEM I, slag and calcined sediments, as illustrated in Table 5 . The main variables considered in this formulation were slag and calcined sediment. According to the standard (EN 196-1) [37], a reference mortar was made up of one-part cement $\left(450 \mathrm{~kg} / \mathrm{m}^{3}\right)$, three parts sand and a half a part water, producing a water/binder ratio of $1 / 2(\mathrm{~W} / \mathrm{B}=0.5)$. A second mortar with addition was obtained by volume replacement of a cement fraction of around $50 \%$ by blast furnace slag. Three other mortars were made by replacing a 50\% fraction of cement with slag and calcined sediments, and the slag was also substituted with a rate of $10 \%, 15 \%$ and $20 \%$ by calcined sediments.

Table 5. Composition of the different mortars formulations.

\begin{tabular}{cccccc}
\hline $\mathbf{K g} / \mathbf{M}^{\mathbf{3}}$ & $\mathbf{C}$ & $\mathbf{C S}$ & CSS 10 & CSS 15 & CSS 20 \\
\hline Sand & 1350 & 1350 & 1350 & 1350 & 1350 \\
CEM I 42.5 R & 450 & 225 & 225 & 225 & 225 \\
Slag & 0 & 208.63 & 166.90 & 146.04 & 125.18 \\
Calcined sediment & 0 & 0 & 39.81 & 59.71 & 79.61 \\
Effective Water (w/b) & 225 & 216.81 & 215.85 & 215.37 & 214.89 \\
Added Water (w/s = 0.4) & 0 & 0 & 15.92 & 23.88 & 31.84 \\
W/B & 0.5 & 0.5 & 0.5 & 0.5 & 0.5 \\
\hline
\end{tabular}

\subsection{Testing Methods}

Several testing methods were performed to study the impact of ternary cement substitution by slag and calcined sediment. 


\subsubsection{Thermogravimetry (TG/DTG) and Paste Mixing}

The thermogravimetric and differential thermal analysis (TG/DTA) were performed on the raw sediment and at a heating rate of $3{ }^{\circ} \mathrm{C} / \mathrm{min}$ in temperatures that varied from 105 to $1000{ }^{\circ} \mathrm{C}$; this thermal method can determine a relationship between mass loss of raw sediment and the mineralogical effect of the temperature treatment.

All pastes were mixed in the required proportions, homogenised and mixed by hand for $1 \mathrm{~min}$. The binder ratio was kept at 0.5 with curing for 28 days in water at $20^{\circ} \mathrm{C}$. The hydration of pastes was stopped by washing with acetone, then crushed by hand and dried in a desiccator. Thermogravimetric tests were carried out by using a NETZSCH apparatus. Powdered dry pastes were assessed with a heating rate of $3{ }^{\circ} \mathrm{C} / \mathrm{min}$ up to $1000^{\circ} \mathrm{C}$.

\subsubsection{Hydration Heat Test}

The heat of hydration test of mortars with the calcined sediments was measured by a semi-adiabatic calorimeter (Langavant method), according to the standard NF EN 196-9 [39]. The test aims to progressively measure the hydration heat of the different mortars studied during the first 7 days. The expression of hydration heat is deduced from the following expression (1):

$$
\mathrm{Q}=\frac{\mathrm{C}}{M c} \theta t
$$

where

$C=$ total heat capacity $(\mathrm{J} / \mathrm{k})$;

$\mathrm{Q}=$ heat of hydration $(\mathrm{J} / \mathrm{g})$;

$\theta t=$ temperature difference between the reference cell and measuring cell $(\mathrm{k})$;

$M c=$ mass of cement $(\mathrm{g})$.

\subsubsection{Mechanical Performance}

For compressive and flexural strength determination, several prismatic samples measuring $4 \times 4 \times 16 \mathrm{~cm}$ (NF EN 196-1) [37] were tested at each of 7, 28 and 90 days' maturation, and all mortars were kept at a temperature of $20^{\circ} \mathrm{C} \pm 2{ }^{\circ} \mathrm{C}$ with a load rise of $2400 \mathrm{~N} / \mathrm{s} \pm$ $200 \mathrm{~N} / \mathrm{s}$ and $50 \mathrm{~N} / \mathrm{s} \pm 10 \mathrm{~N} / \mathrm{s}$ for compressive and flexural strength, respectively.

\subsubsection{Dynamic Young's Modulus}

The dynamic Young's modulus of mortar was performed according to the standard NF EN 1097-7 [40] by using a Grindo Sonic apparatus. The tests were carried out on mortar prismatic specimens at 1, 7, 14, 28, 60 and 90 days. It consists of exciting vibrations by striking the mortar prism with tapping apparatus. Data acquisition was conducted by recording the resonant frequency of the system during excitation. The dynamic modulus of elasticity is measured according to density and resonant frequency at each number of curing days.

\subsubsection{Mercury Porosity}

Porosity measurements were performed by mercury porosimetry on mortar fragments (NF p 94-410-3) [41]. The fragments of mortars are cut into $1 \mathrm{~cm}$ cubes [42-44]. This method provides quick access to pore dispersion, with good precision in the range of $3 \mathrm{~nm}$ to $360 \mu \mathrm{m}$ for mercury pressures up to 30,000 psi (206 MPa).

\subsubsection{Scanning Electron Microscopy (SEM) Analysis}

In order to understand the microstructure of reference mortar and mortar containing calcined sediment and slag at 90 days, scanning electron microscopy (SEM) was performed by using a JEOL scanning electron microscope (SEM) operating with a $15 \mathrm{Kv}$ acceleration voltage. 


\subsubsection{Leaching Analysis}

Leaching tests were performed on mortar fragments containing slag and calcined sediment in order to analyse the trace elements mobility according to the BS EN 12457-2 [45] by using an inductively coupled plasma atomic emission spectrometer (ICP-AES) with an Agilent Technologies SPS4 Autosampler. The single-stage leaching tests are carried out by using a liquid-to-solid ratio of 10:1 mL/g.

\section{Results and Analyses}

\subsection{Thermogravimetric Analysis (TGA) of Raw Sediments}

Thermogravimetric and differential thermal analyses (TG/DTA) were performed on the raw sediment. Figure 4 presents the results of the raw sediment and it demonstrated the following.

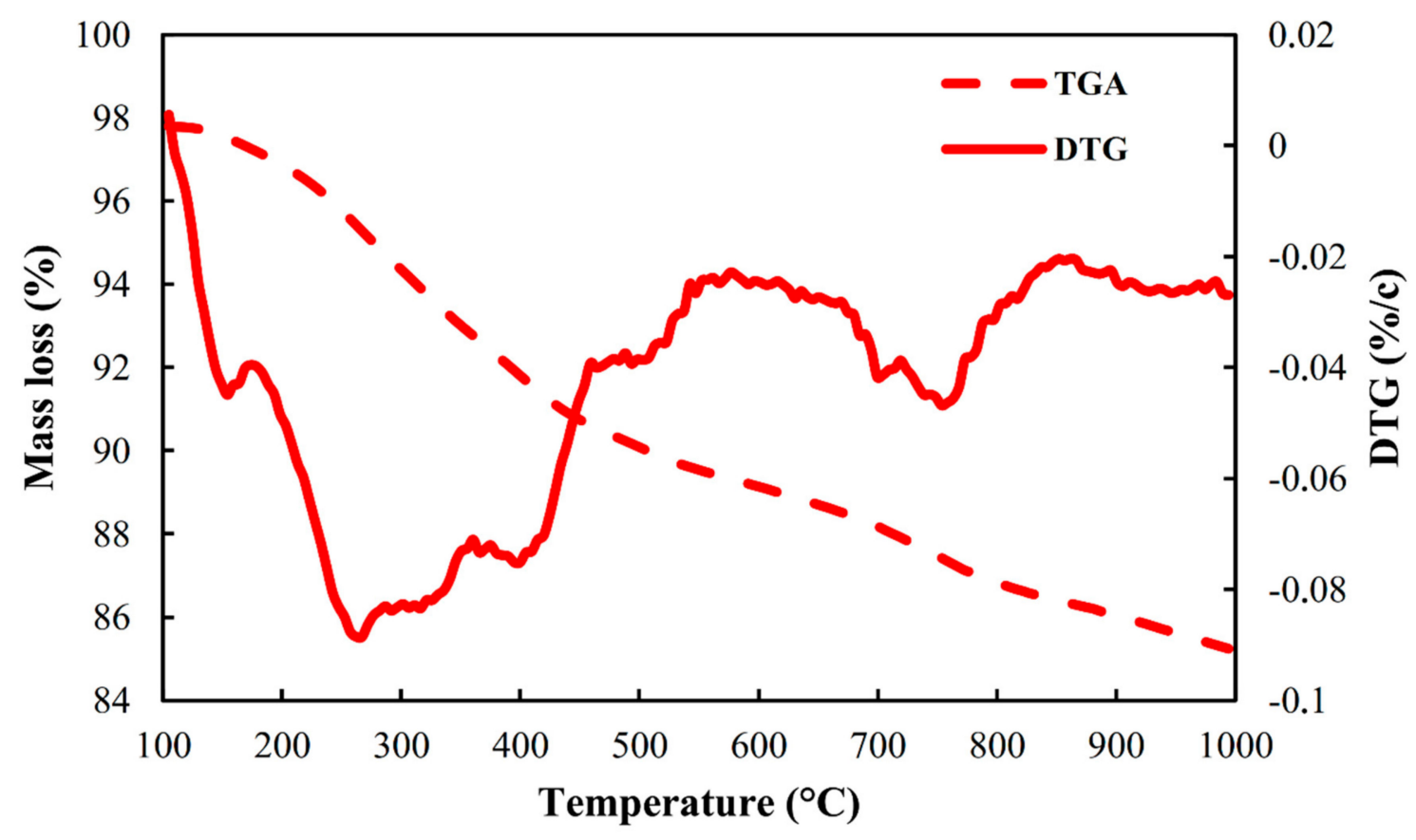

Figure 4. DTA/TG analysis of raw dredged sediment.

Dehydration phase $\left(105-220^{\circ} \mathrm{C}\right)$ : At low temperatures, the free water and some of the interlayer water evaporates from the raw material. This is followed by limited loss of mass for raw sediment due to the swelling clay capacities (the sediment is rich in muscovite and low-crystallinity illite) [46-49].

Dehydroxylation phase $\left(450-709^{\circ} \mathrm{C}\right)$ : Further mass loss was observed from $450{ }^{\circ} \mathrm{C}$ to $709^{\circ} \mathrm{C}$. The loss of $\mathrm{H}_{2} \mathrm{O}$ relates to the water content of clay minerals from the $\mathrm{OH}$ groups contained in the clay $[47,50]$. The exothermic decomposition of organic matter would also be expected to occur between $450{ }^{\circ} \mathrm{C}$ and $550{ }^{\circ} \mathrm{C}$. At this temperature range numerous other chemical reactions may also occur: As kaolinite changed to metakaolinite, structural transformation and loss of crystallinity occurred [51], along with the transition of a-quartz, to b-quartz [52]. Similarly, illite changes into dehydrated illite [53,54].

Decarbonisation phase $\left(758-930{ }^{\circ} \mathrm{C}\right)$ : Att this level, limestone $\left(\mathrm{CaCO}_{3}\right)$ is decomposed into calcium oxide $\mathrm{CaO}$ with emissions of carbon dioxide $\left(\mathrm{CO}_{2}\right)$. The decarbonisation of calcite is related to a significant loss of mass [47] beginning at $750{ }^{\circ} \mathrm{C}$ with of up to $44 \%$ mass loss in $\mathrm{CO}_{2}$ for pure calcite [55]. The residual $\mathrm{CaO}$ created as the calcite may impact the reactivity of this calcined sediment $[53,56]$. However, the carbonate content of this sediment is naturally limited by the geology of the source area in which carbonate-rich lithologies are scare. 
Recrystallisation phase: This is associated with an exothermic change without a loss of mass at temperatures over $900{ }^{\circ} \mathrm{C}$, which can also result in a loss of pozzolanic reactivity $[46,48]$. Thus, the optimum temperature for calcination acquiring pozzolanic material should be between the end of dehydroxylation and the beginning of recrystallisation [57], which denotes the range between 700 and $900{ }^{\circ} \mathrm{C}$ when utilising sediment. This evaluation affirms that the optimum calcination temperature for achieving material activation is around $750{ }^{\circ} \mathrm{C}$ so as to achieve full dehydroxylation while minimising any additional decomposition of carbonates and $\mathrm{CO}_{2}$ emissions.

\subsection{Thermogravimetry Analysis (TG/DTG) of Different Mixtures}

Figure 5 shows the amounts of portlandite produced at 28 days of curing in water. The results show three major phases associated with the decomposition of hydrates of AFm phases and C-S-H, with high loss of water between $150{ }^{\circ} \mathrm{C}$ and $430{ }^{\circ} \mathrm{C}$. Furthermore, the dehydroxylation of $\mathrm{Ca}(\mathrm{OH})_{2}$ corresponds to the endothermic peak between $440{ }^{\circ} \mathrm{C}$ and $690{ }^{\circ} \mathrm{C}$. The last phase between $700{ }^{\circ} \mathrm{C}$ and $860^{\circ} \mathrm{C}$ corresponds to the decarbonation of calcium carbonates (CC). For the paste mixtures, CS, CSS10\% and CSS15\% pastes revealed significantly stronger hydrates compared to control paste, with increased formation of $\mathrm{C}-\mathrm{S}-\mathrm{H}$ and AFm content in these pastes. Notably, the ettringite content is comparable in all mixtures pastes [58]. The second peak of portlandite (for $\left.\mathrm{Ca}(\mathrm{OH})_{2}\right)$ around $480{ }^{\circ} \mathrm{C}$ for the control paste $(\mathrm{C})$ is much stronger than in the other mixture pastes (pastes made with slag and calcined sediment), indicating a larger quantity of $\mathrm{Ca}(\mathrm{OH})_{2}$ compared to the other mixtures pastes. The presence of portlandite in hydrated mixtures can play a major role in pouzzolanic reaction $[59,60]$. Finally, the decarbonation is observed with a small peak for the different pastes above $900{ }^{\circ} \mathrm{C}$. The cement paste $(\mathrm{C})$ has a much weaker decarbonation peak compared to the other mixtures due to the lower content of calcite $\mathrm{CaCO}_{3}$. A significant quantity of calcite has been observed in the slag paste compared to the different pastes based on slag and calcined sediment at a rate of $10 \%, 15 \%$ and $20 \%$ [61] in which the sediment replaces roughly one-third of the slag.

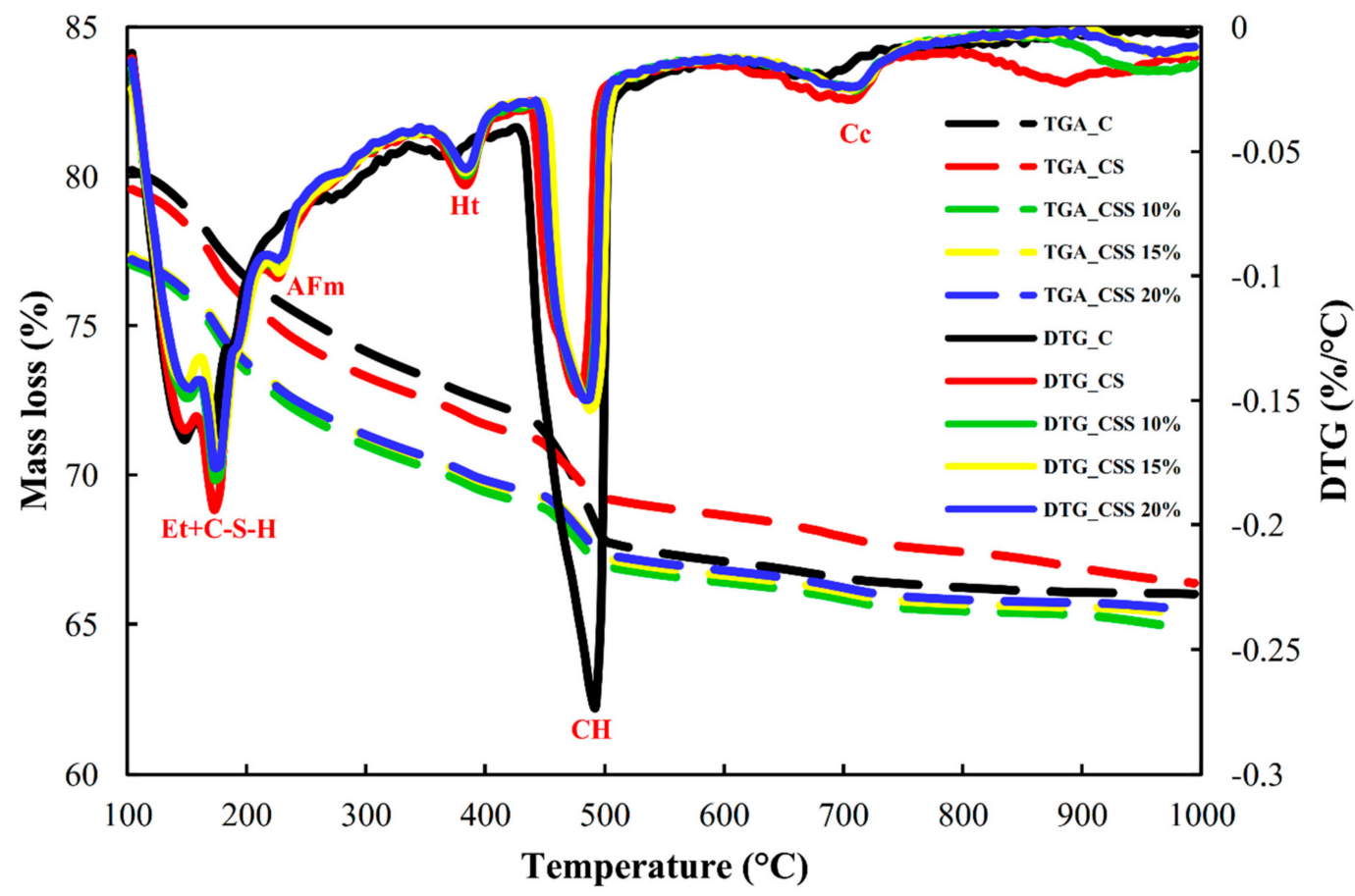

Figure 5. TGA/DTG of different pastes at 28 days of curing. (Et): Ettringite; (AFm): monosulphate; hemicarbonate and monocarbonate; (C-S-H): C-S-H phase; $(\mathrm{CH})$ : Portlandite; and $(\mathrm{Cc})$ : calcium carbonate. 


\subsection{Hydration Heat Test}

Figure 6 shows the hydration rate and cumulative heat of hydration of the different mortars containing slag and calcined sediment (C, CS, CSS10\%, CSS15\% and CSS20\%) at $20^{\circ} \mathrm{C}$ for up to $150 \mathrm{~h}$. The reference mortar (C) has a lower induction period with a faster hydration rate. It has a significant peak at around $13.28 \mathrm{~h}$ with $28.69 \mathrm{~J} / \mathrm{g}$ heat, which corresponded to the rapid formation of C-S-H, CH and ettringite. It can be observed that the CSS15\% mortar generated $23.21 \mathrm{~J} / \mathrm{g}$ of heat at around $15 \mathrm{~h}$, and the CSS20\% mortar generated $18.64 \mathrm{~J} / \mathrm{g}$ of heat at around $16 \mathrm{~h}$, while the CS and CSS10\% mortars generated $12.25 \mathrm{~J} / \mathrm{g}$ and $12.51 \mathrm{~J} / \mathrm{g}$ of heat at around $18 \mathrm{~h}$, respectively. It should also be noted that the sharpness of the thermal peak can be attributed to the high stiffness of calcined sediment and slag [59].

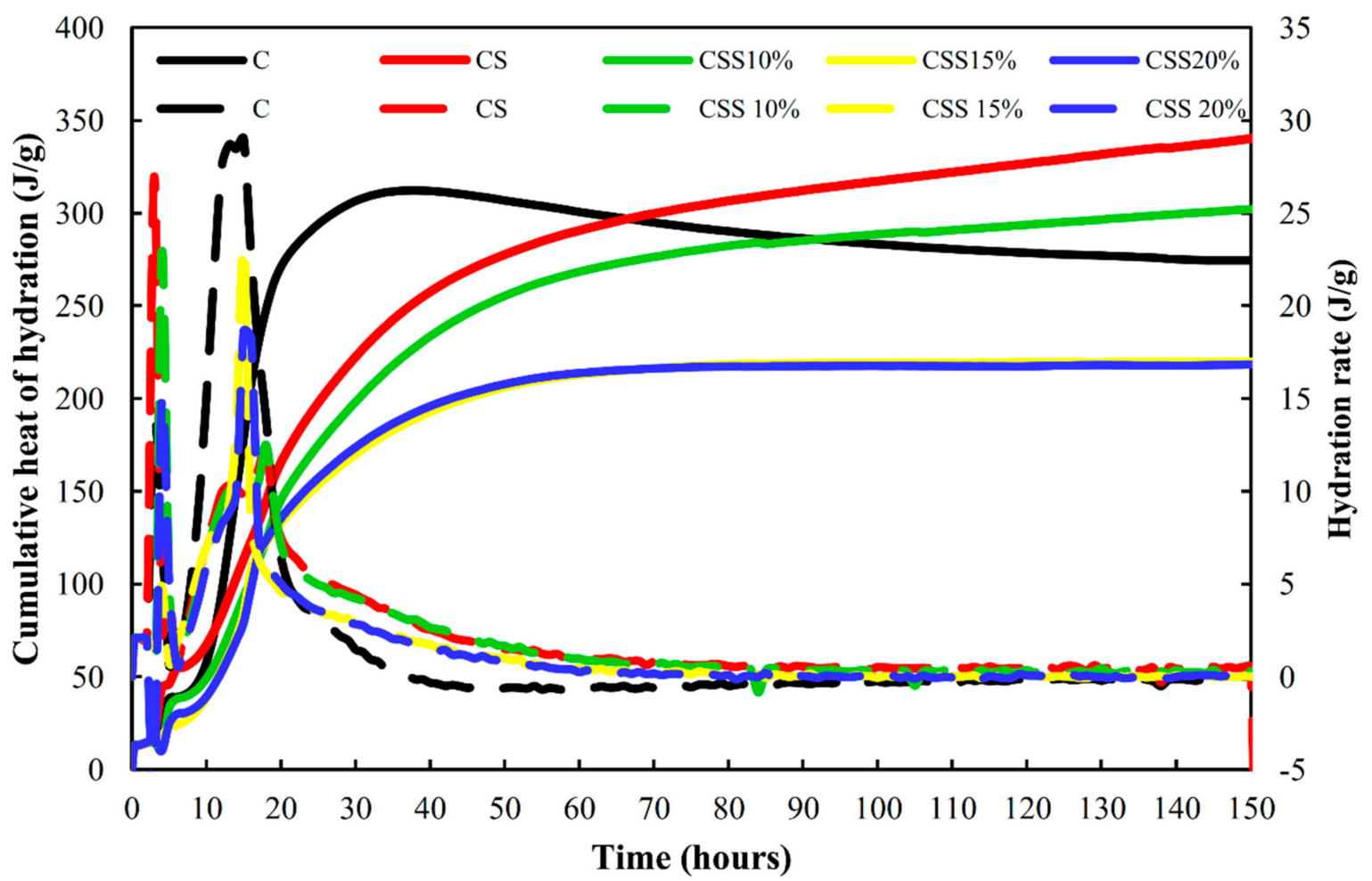

Figure 6. The heat flow and total heat of hydration of the different mortars containing slag and calcined sediment (C, CS, CSS10\%, CSS15\% and CSS20\%).

The highest cumulative heat of hydration is obtained for the CS and CSS10\% mortars with $329.45 \mathrm{~J} / \mathrm{g}$ of heat and $306.66 \mathrm{~J} / \mathrm{g}$ of heat, while $274.60 \mathrm{~J} / \mathrm{g}$ of heat is reported for reference mortar (C). By contrast, the much less cumulative heat of hydration is obtained for the CSS15\% and CSS20\% mortars with $219.45 \mathrm{~J} / \mathrm{g}$ of heat and $218.14 \mathrm{~J} / \mathrm{g}$ of heat, respectively. The highest cumulative heat of hydration for the CS and CSS10\% mortar is attributed to the combination effect of slag and calcined sediment up to $10 \%$ of substitution [62]. The hydration heat generated with slag and calcined sediment in combination with cement CEM I 42.5 R is likely due to the pozzolanic reaction into calcium-silicate -hydrates (CS-H) [47]. It also could be that a higher substitution level of calcined sediment by slag generated less cumulative heat of hydration [62]. Hence, the optimum substitution rate of calcined sediment that can be used is $10 \%$. The outcomes agree with previous studies on the heat of hydration with calcined sediment and calcined clay [62-64]. 


\subsection{Mechanical Performance \\ 3.4.1. Compressive Strength of Mortars}

The results of the evolution of the compressive strength of mortars formulated with slag and calcined sediment are shown in Figure 7. From these figures, the results of the compressive strengths of mortars based on $50 \%$ cement and $50 \%$ of blast furnace slags (CS) show a decrease in compressive strengths to $27.43 \mathrm{MPa}$ and $49.77 \mathrm{MPa}$ after 7 days and 28 days compared to the control mortar $(\mathrm{C})$, which presents resistances at the order of $46.06 \mathrm{MPa}$ and $54.56 \mathrm{MPa}$, respectively, after 7 and 28 days. The impacts of slag contribution on strength during the early period are not visible. However, at a later period, it appears to be more significant $[65,66]$. Mortars based on $50 \%$ cement and a substitution dosage of slag by calcined sediments of the order of 10,15 or $20 \%$ show only a slight deterioration in compressive strength to around $46.09 \mathrm{MPa}, 42.86 \mathrm{MPa}$ or $42.71 \mathrm{MPa}$ at 28 days. A linear increase in compressive strength of each mixture was maintained for 90 days for the different types of mortars irrespective of the partial substitution of cement by slag and calcined sediments. Smaller reductions in the compressive strengths of mortars composed of $50 \%$ cement, $40 \%$ slag and $10 \%$ calcined sediment were observed after 90 days compared to the control. This affirms previous results announced by Bougara $[12,13,67]$, which exhibits that the early strength is essentially dictated by the fineness of the ordinary Portland cement OPC fraction and later by the slag fraction. These reductions in compressive strength were reduced to $92.73 \%$ at 90 days. These same results are consistent with what has been described in the literature regarding the substitution of cement by slag $[12,68]$ and calcined sediments $[69,70]$.

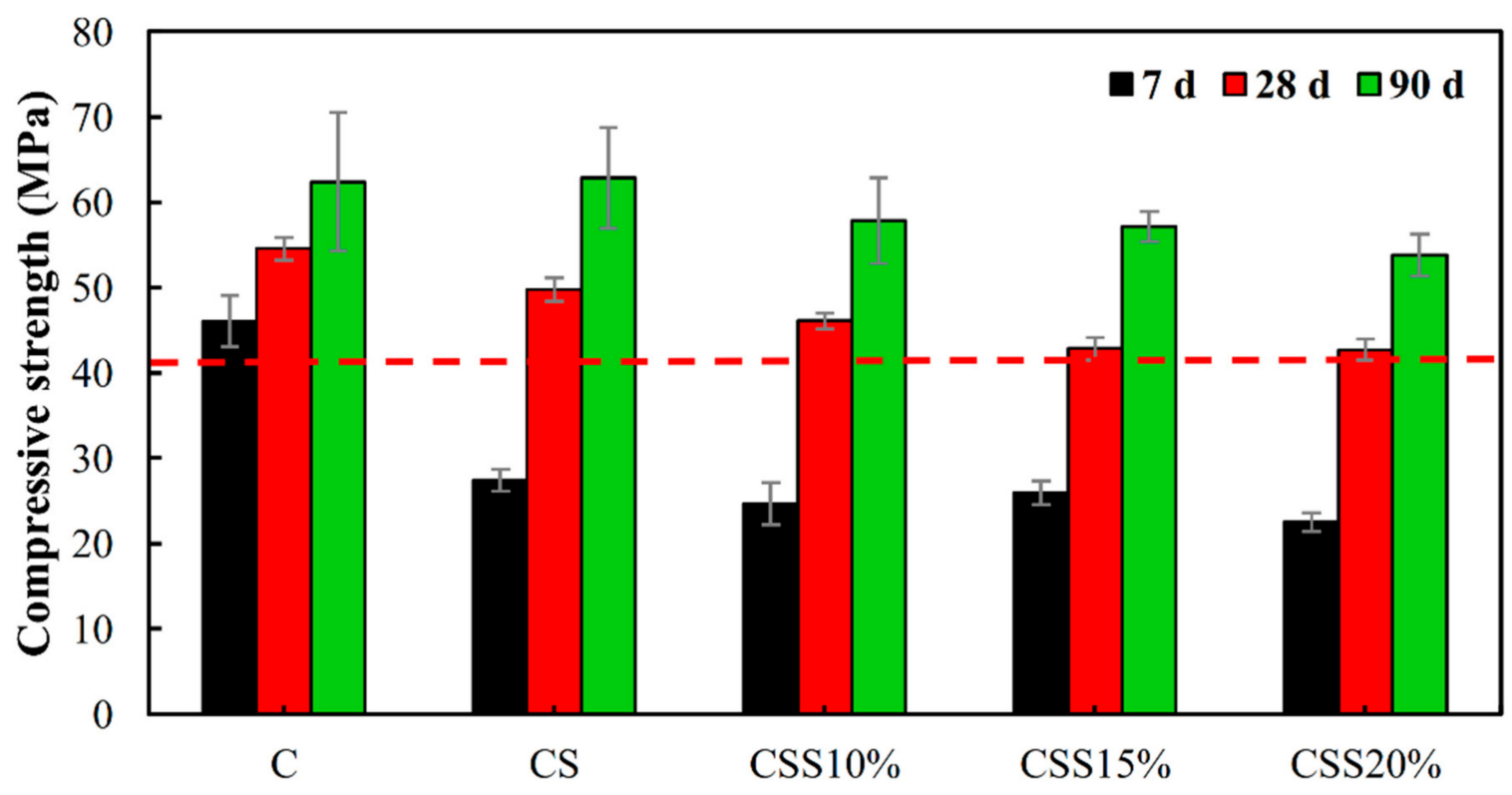

Figure 7. Compressive strength of mortars with slag and calcined sediment.

\subsubsection{Flexural Strength of Mortars}

The effects of the flexural strength development of mortar specimens formulated with slag and calcined sediment are clearly shown in Figure 8. It is easily observed that the flexural strength of all mortars increments consistently with age and shows no decrease in strength. From our investigation, it was generally expressed that the incorporation of slag and calcined sediment has limited effects on the flexural strengths after more than 7 days at all substitution rates. 


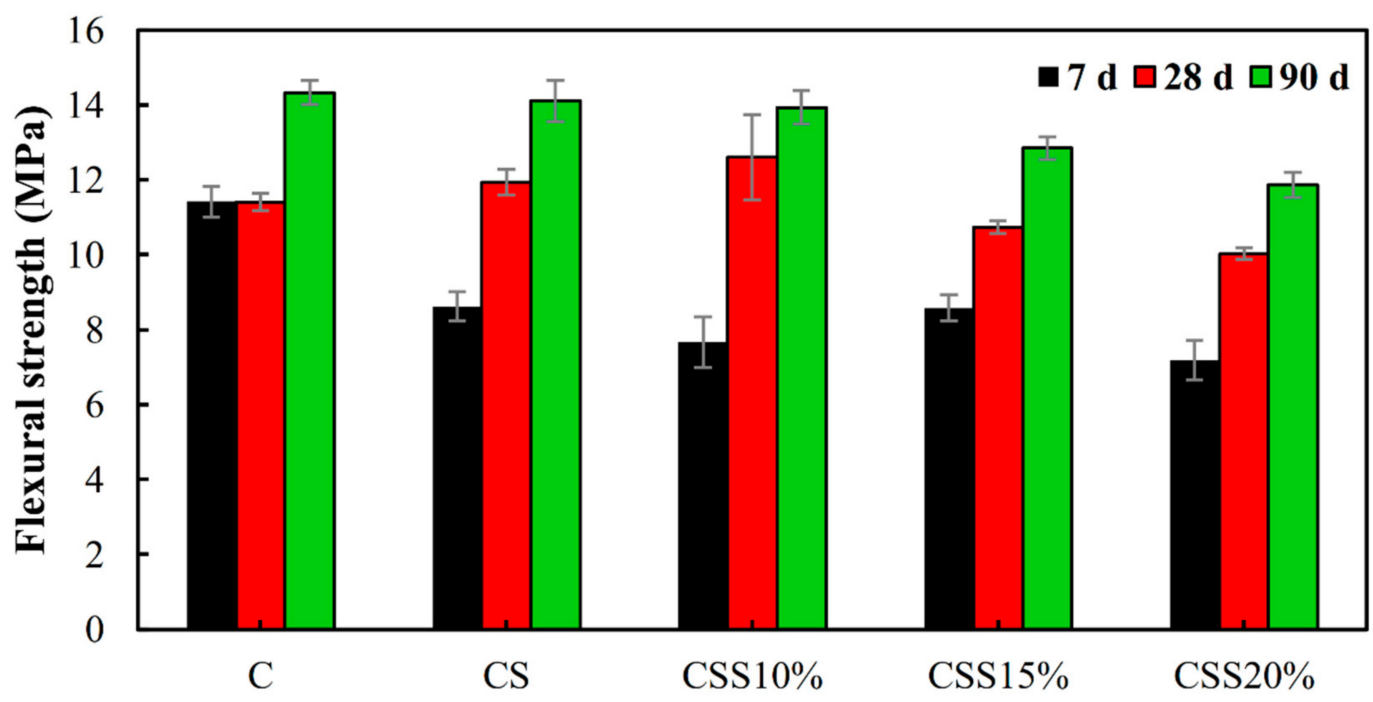

Figure 8. Flexural strength of mortars with slag and calcined sediment.

\subsection{Dynamic Young's of Mortar of the Different Mortars}

Dynamic Young's moduli of the different mortars from 1 to 90 days are shown in Figure 9. The results show an increase in dynamic Young's modulus with age from 1 to 90 days. At an early age, the reference mortar (C) had a Dynamic young's of $36.47 \mathrm{GPa}$ compared to $29.98 \mathrm{GPa}, 29.33 \mathrm{GPa}, 29.64 \mathrm{GPa}$ and $29.93 \mathrm{GPa}$ for the CS, CSS10\%, CSS15\% and CSS20\% mortars at 7 days, respectively. After 28 days, all mortar with slag and calcined sediment seems to show the same values of dynamic Young's modulus with very small increases in $33.84 \mathrm{GPa}, 33.16 \mathrm{GPa}, 33.89 \mathrm{GPa}$ and $34.15 \mathrm{GPa}$ for the CS, CSS10\%, CSS15\% and CSS20\% mortars at 28 days, respectively. From 60 and 90 days, all mortars show the same trend with a low increase at 90 days. Hence, the evolution of dynamic Young's modulus of the different mortars followed the ongoing trend of increasing compressive strength with age. It indicated the good quality of mortar containing slag and calcined sediment due to the ongoing pozzolanic reaction.

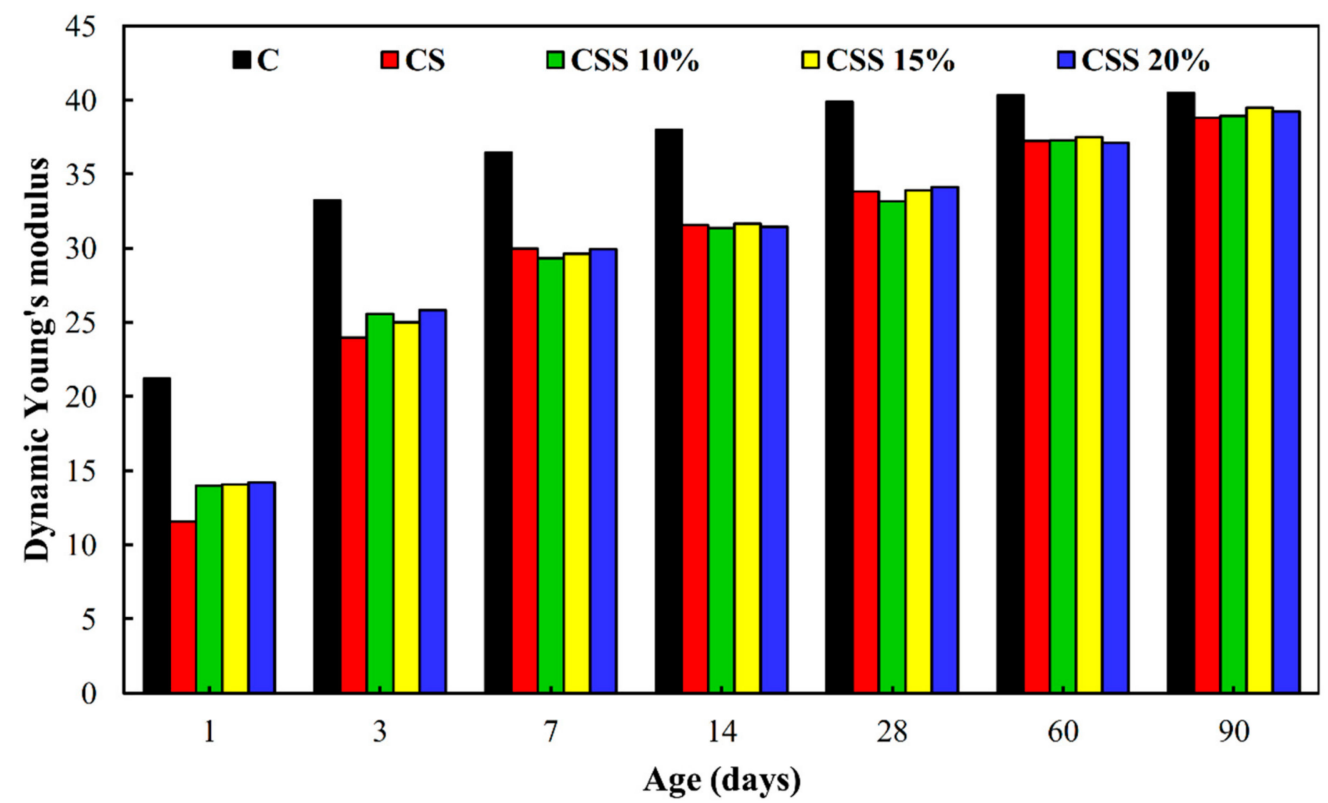

Figure 9. Dynamic young's modulus of the different mortars from 1 to 90 days. 


\subsection{Mercury Porosity}

Table 6 shows a linear decrease in porosity with age for all mortars studied. However, a higher porosity can be observed at 7 days and 28 days for mortars based on $50 \%$ cement, $30 \%$ slag and $20 \%$ calcined sediment with $18.02 \%$. This variation is typical. It is the consequence of the latent hydration of the slag and calcined sediment. This is widely confirmed in the literature [71]. The mortar based on 50\% cement and 50\% slag (CS) is also coarser than the control mortar (C) (Table 6). However, after 90 days of curing; the pore size distribution of cement-based mortars substituted by slag and calcined sediments of the order of $10 \%$ is even smaller and finer than the control mortar (C), which is consistent with an evolving reduction in pore size. These results can be explained by the hydration of the slag and calcined sediments after the consumption of

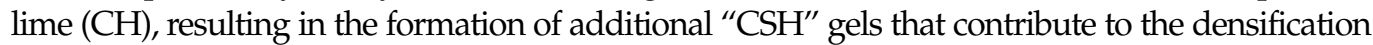
of the porous structure of the matrix [72,73]. In contrast, the mortar with slag and slightly more calcined sediment (CSS20\%) has an increased pore volume compared to the reference mortar (C). It could be due to higher porosity of calcined sediment and the new C-S-H gel produced [73].

Table 6. Total porosity of the cementitious matrix studied.

\begin{tabular}{cccc}
\hline Total Porosity of the Cementitious Matrix (\%) & 7 Days & 28 Days & 90 Days \\
\hline C & 11.69 & 10.33 & 9.95 \\
CS & 15.33 & 11.71 & 9.22 \\
CSS 10\% & 14.35 & 12.29 & 9.60 \\
CSS 15\% & 15.55 & 12.43 & 10.76 \\
CSS 20\% & 18.02 & 13.30 & 12.49 \\
\hline
\end{tabular}

Figure 10 shows the results of the distribution of cumulative and differential pore size for different mortars between 7, 28 and 90 days (Figure 10a-c). At 7 days the pore size and cumulative volume of different mortars with slag and calcined sediment are higher than the reference mortar (C). At 28 days, the pore size distribution of mortar with slag and calcined sediment replacement with $10 \%, 15 \%$ and $20 \%$ seems to show the same cumulative pattern, with a decreasing modal pore size from $0.062 \mu \mathrm{m}$ of reference mortar (C) to $0.032 \mu \mathrm{m}, 0.017 \mu \mathrm{m}, 0.021 \mu \mathrm{m}$ and $0.026 \mu \mathrm{m}$ for the CS, CSS10\%, CSS15\% and CSS20\% mortars, respectively (Figure 10b). At 90 days, the pore size distributions of mortar with slag (CS) and mortar with slag and calcined sediment (CSS15\%) were significantly reduced to finer and denser micro-pores with less total porosity [63,73] (Figure 10c). However, when the substitution rate of cement with slag and calcined sediment exceeds $15 \%$, an increase in porosity is shown due to the higher fineness of calcined sediment and lower pozzolanic reaction (due to a lower content of metakaolinite in calcined sediment) [64]. Table 5 shows the total volume porosity $(p)$ values.

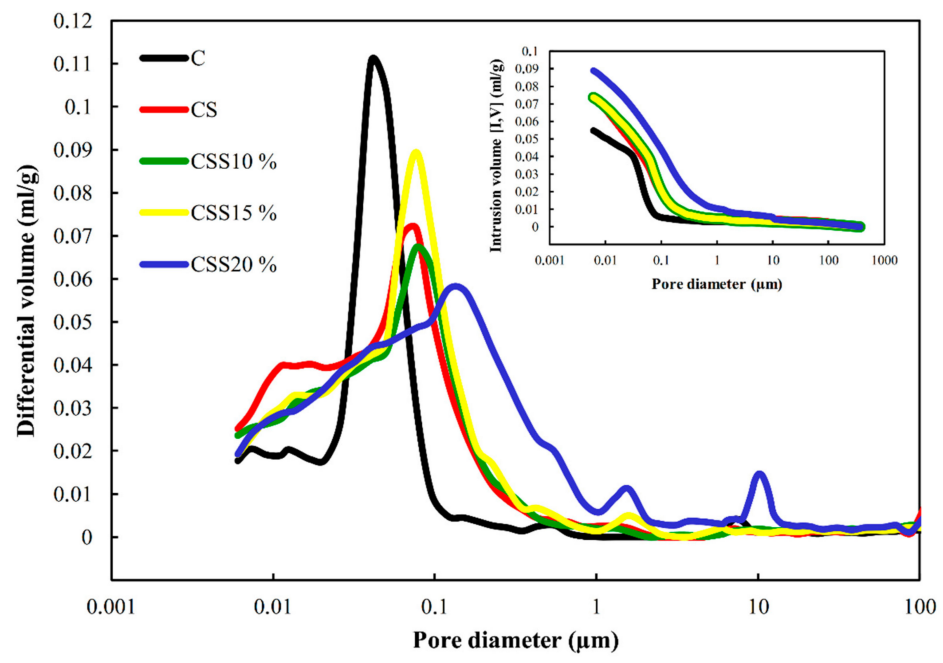

(a)

Figure 10. Cont. 


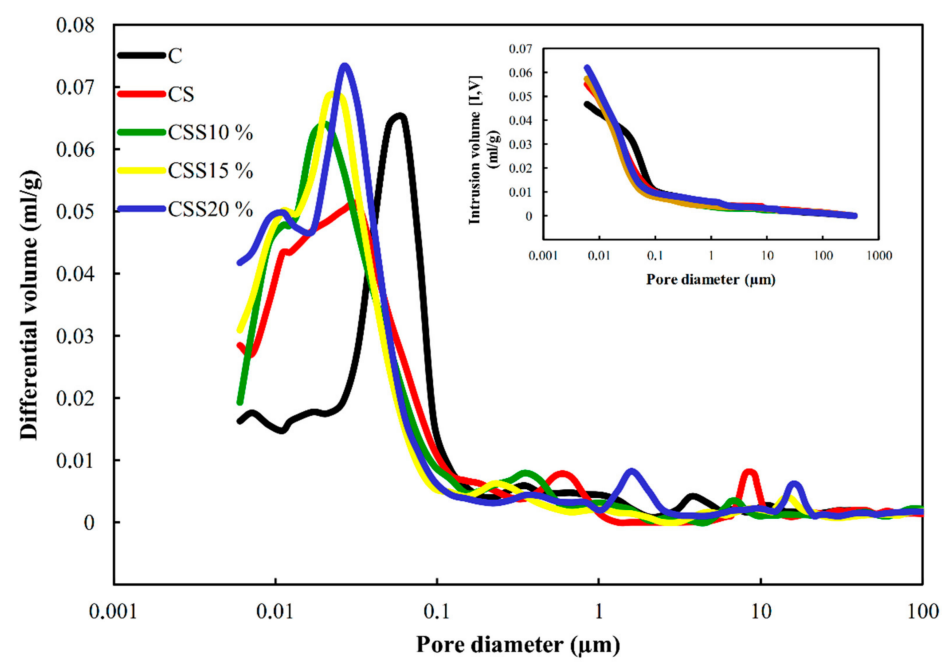

(b)

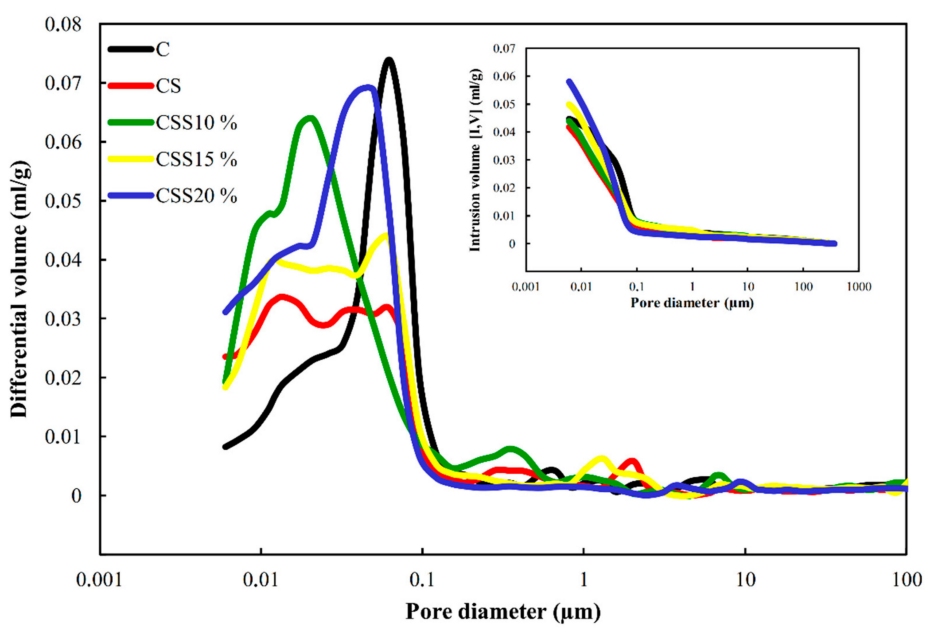

(c)

Figure 10. (a). Distribution of cumulative and differential pore size for different mortars at 7 days. (b). Distribution of cumulative and differential pore size for different mortars at 28 days. (c). Distribution of cumulative and differential pore size for different mortars at 90 days.

\subsection{Microscopic Observation}

The microstructures of different mortars with slag and calcined sediment and reference mortar after 90 days of cure are shown in Figure 11. The reference mortar (C) shows a structure of hydration products (C-S-H) and significant amounts of portlandite combined to ettringite. However, the mortar with slag (CS) and the mortar with slag and calcined sediment with a substitution rate of $10 \%$ (CSS10\%) are denser with a decrease in porous structure, which can significantly reduce porosity. The contents of portlandite $(\mathrm{CH})$ and ettringite are lower than the reference mortar $(C)$ due to the pozzolanic reaction between slag and calcined sediment, with the formation of amorphous gels (C-S-H, C-A-H and C-A-S-H) [64]. The microscopic observation results agree well with the lower mercury porosity results for the mortar based on slag and the mortar based on slag and calcined sediment (CSS10\%) [73]. On the other hand, the mortars incorporating 15\% and 20\% of calcined sediment (SCC15\% and SCC20\%) appears to be more porous; this may be due to the agglomeration of calcined sediment relative to the incomplete pozzolanic reaction that consumed portlandite $(\mathrm{CH})[53]$. 

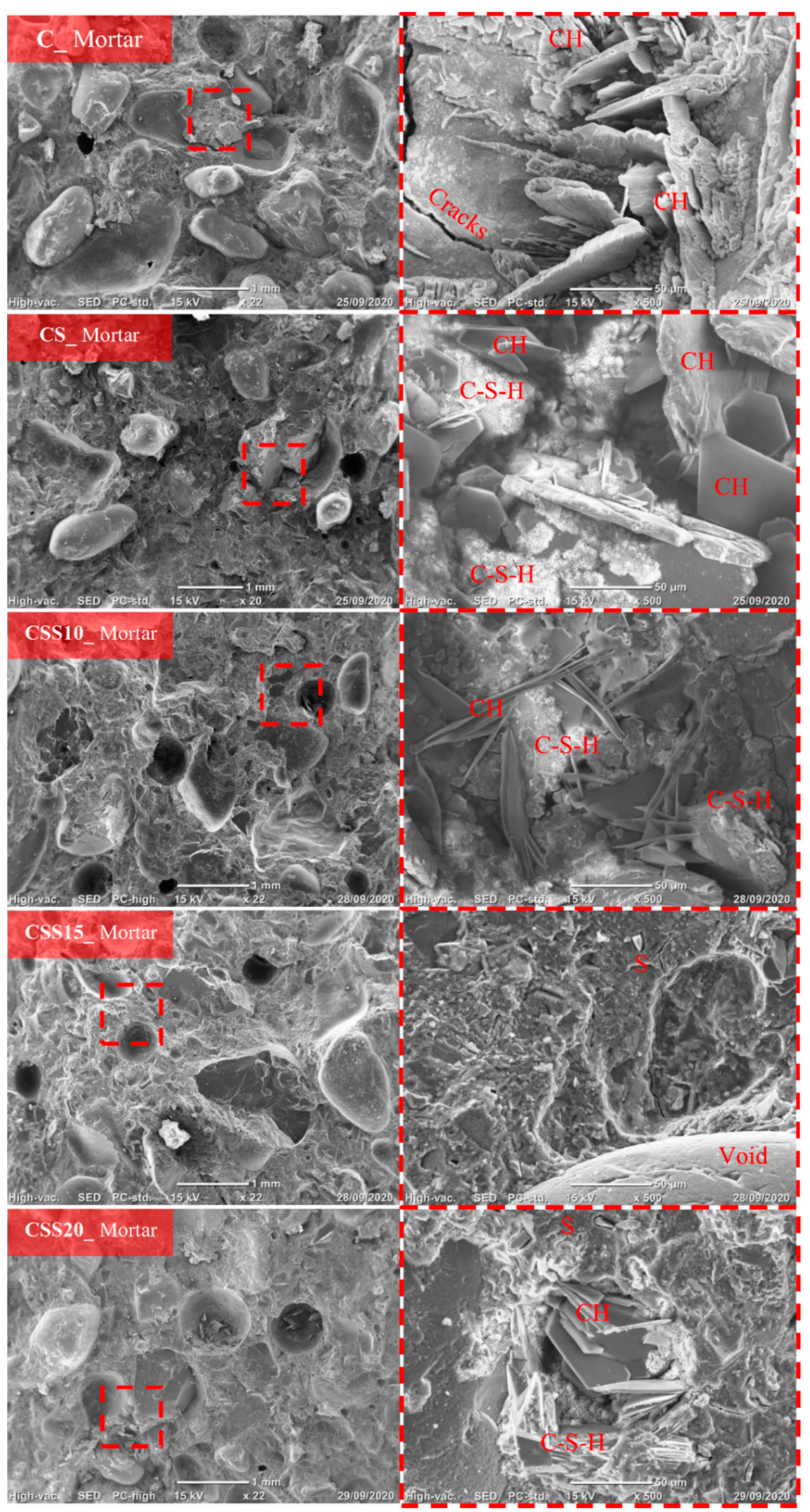

Figure 11. The microstructures of different mortars with slag and calcined sediment compared to the reference mortar. 


\subsection{Leaching Analysis}

The results of the leaching analysis are presented in Table 7 . The limits for classification of inert solid waste are only exceeded by the leachable chromium and the sulfates in the cement and the selenium and sulphate in the calcined sediment. By contrast, the leachable trace elements concentration in the different mortar formulations were reduced by dilution and, thus, fell below the limits for inert solid waste. The barium (Ba) content in the reference mortar (C) also exceeded the limits, but it was diluted by the addition of $50 \%$ slag and or sediment. In general, the substitution of calcined sediment and slag in mortar can also significantly reduced the leachability of any contaminants they contain. These results are close to those found in previous studies $[74,75]$ conducted on the valorisation of marine sediments. It is noted, however, that the chemical composition values of the materials used were lower than the threshold values, while the sediments studied were obtained from a pristine site and would be classified as non-hazardous waste according to French or UK law.

Table 7. Leaching analysis results $(\mathrm{mg} / \mathrm{Kg})$ of raw materials and the different mortars.

\begin{tabular}{|c|c|c|c|c|c|c|c|c|c|c|}
\hline \multirow[b]{2}{*}{ Elements } & \multicolumn{4}{|c|}{ Raw Materials } & \multicolumn{5}{|c|}{ Mortar Based on Slag and Calcined Sediment } & \multirow{2}{*}{$\frac{\text { Limit }}{\text { Inert }}$} \\
\hline & $\mathrm{C}$ & $\mathbf{S}$ & R_SD & C_SD & $\mathrm{C}$ & CS & $\begin{array}{l}\text { CSS } \\
10 \%\end{array}$ & $\begin{array}{c}\text { CSS } \\
15 \%\end{array}$ & $\begin{array}{l}\text { CSS } \\
20 \%\end{array}$ & \\
\hline As & $<0.1$ & $<0.1$ & $<0.1$ & 0.39 & $<0.1$ & $<0.1$ & $<0.1$ & $<0.1$ & $<0.1$ & 0.50 \\
\hline $\mathbf{B a}$ & 10 & $<0.02$ & 1.2 & 0.61 & 22.5 & 11 & 13 & 13 & 13 & 20.0 \\
\hline Cd & $<0.01$ & $<0.01$ & $<0.01$ & $<0.01$ & $<0.009$ & $<0.009$ & $<0.009$ & $<0.009$ & $<0.009$ & 0.04 \\
\hline $\mathrm{Cr}$ & 1.5 & $<0.03$ & $<0.03$ & 0.049 & $<0.004$ & $<0.004$ & $<0.004$ & $<0.004$ & $<0.004$ & 0.50 \\
\hline $\mathrm{Cu}$ & $<0.03$ & $<0.03$ & 0.12 & $<0.03$ & $<0.02$ & $<0.02$ & $<0.02$ & $<0.02$ & $<0.02$ & 2.00 \\
\hline Mo & 0.29 & $<0.05$ & $<0.05$ & 1.0 & $<0.09$ & $<0.09$ & $<0.09$ & $<0.09$ & $<0.09$ & 0.50 \\
\hline $\mathrm{Ni}$ & $<0.05$ & $<0.05$ & 0.093 & $<0.05$ & $<0.05$ & $<0.05$ & $<0.05$ & $<0.05$ & $<0.05$ & 0.40 \\
\hline $\mathrm{Pb}$ & 0.054 & $<0.02$ & $<0.02$ & 0.068 & 0.045 & $<0.03$ & $<0.03$ & $<0.03$ & $<0.03$ & 0.50 \\
\hline $\mathrm{Sb}$ & $<0.06$ & $<0.06$ & $<0.06$ & $<0.06$ & $<0.06$ & $<0.06$ & $<0.06$ & $<0.06$ & $<0.06$ & 0.06 \\
\hline Se & $<0.08$ & $<0.08$ & $<0.08$ & 0.12 & $<0.08$ & $<0.08$ & $<0.08$ & $<0.08$ & $<0.08$ & 0.10 \\
\hline $\mathrm{Zn}$ & $<0.05$ & $<0.05$ & 0.47 & $<0.05$ & 0.014 & $<0.01$ & $<0.01$ & $<0.01$ & $<0.01$ & 4.00 \\
\hline Fluorides & $<1.0$ & 5.8 & 21 & 1.0 & 3.0 & 4.0 & 3.0 & 3.0 & 3.0 & 10.0 \\
\hline Chlorides & 217 & 60 & 23 & $<10$ & 22 & 15 & 29 & 29 & 29 & 800 \\
\hline Sulfates & 2320 & 31 & 120 & 1670 & 23 & 24 & 22 & 38 & 30 & 1000 \\
\hline
\end{tabular}

\subsection{Energy and Greenhouse Gas Emission Considerations}

The results presented above suggest that low temperature calcined canal sediments could successfully substitute for GGBS when it is used to partially replace Portland cement in mortars while simultaneously producing enhanced mechanical performance. This could create a use for waste sediment and reduce the material costs and emissions associated with GGBS production and transportation [76]. Conversely, the calcination of sediment requires thermal energy for drying and processing the sediment and produces additional $\mathrm{CO}_{2}$ emissions from any organic matter content or partial decomposition of any carbonates it contains. Analyses of these Scottish canal sediments provide average total organic carbon and carbonate equivalent contents of 6.3 and $2.9 \%$, respectively. From stoichiometry, these would generate emissions of $2.4 \mathrm{t}$ and $0.013 \mathrm{t} \mathrm{CO}_{2}$, respectively, assuming complete oxidation of organic carbon and decomposition of an equivalent amount of pure $\mathrm{CaCO}_{3}$.

Thus, the net emissions reductions are most sensitive to the organic matter content of the canal sediment. Elsewhere in the Scottish Lowland canal network, organic carbon contents can be up to $18 \%$, which is equivalent to loss on ignition levels exceeding $30 \%$. Once organic $\mathrm{C}$ content reaches $21.5 \%$, it will generate $1 \mathrm{t}$ of additional $\mathrm{CO}_{2}$ per $\mathrm{t}$ of burnt sediment, thereby effectively cancelling out any benefit in terms of greenhouse gas emissions from their substitution for cement. By comparison, direct substitution of Portland cement by GGBS alone will reduce $\mathrm{CO}_{2}$ equivalent emissions from $0.95 \mathrm{t}$ to $0.07 \mathrm{t}$ per tonne of material used [33]. 
Furthermore, the canal sediment samples collected from Laggan contained only $22-33 \%$ dry matter as received, typifying the high water content when dredged. Elsewhere during the Suricates project, passive dewatering experiments have so far achieved water contents of $60-65 \%$ by natural drying in the temperate and oceanic Scottish climate. Assuming a worst case of $35 \%$ dry matter content, the latent heat of evaporation required alone indicates a minimum energy use of $420 \mathrm{MJ}$ per dry tonne of sediment. Following this the expected energy consumption of the subsequent calcination step, $2 \mathrm{GJ} / \mathrm{t}$ of sediment is expected, which still compares favourably overall with the $8 \mathrm{GJ} / \mathrm{t}$ typically required for pure cement clinker. However, the estimated energy imputs required for dried calcined sediment are still higher than the $1.3 \mathrm{GJ} / \mathrm{t}$ claimed for GGBS [33].

\section{Conclusions}

Sedimentation represents a considerable challenge for maintaining ports, canals and reservoirs. The sediment deposits will reduce the storage capacity or decrease the energy efficiency of navigation. Sedimentation control is always possible by hydraulic or mechanical dredging operations but produces potential waste. The best option would be to valorise this sediment. This study aimed to use slag and calcined sediment from Scotland as a partial replacement in Portland cement. This could generate binders with comparable or greater characteristics than Portland cement without additions.

From the results of our experimental investigation, it is evident that this study has shown the following:

- These results could reduce the environmental impact of dredging by reusing sediment from ports and canals. Sediments can be useful in the circular economy, while simultaneously reducing greenhouse emissions and the consumption of natural resource consumption by partial substitution of cement for slags and calcined sediments. In North-West Europe, these products could help to combat flooding or to mitigate the impacts of climate change.

- On the other hand, these same results can reduce the financial costs of dredging through the valorisation of calcined sediments and slag as co-products in the manufacturing of cement.

- The physical and chemical characterisation of the calcined sediments revealed a good pozzolanic character that can be valorised as a co-product in the cement industry.

- Mineralogical analysis (XRD) of dredged sediments has shown that sediments from the Caledonian Canal in the Scottish Highlands are rich in muscovite, illite, quartz and albite.

- The thermogravimetric analysis (TGA/DTG) allowed the determination of the optimum calcination temperature for producing an artificial pozzolanic material; the temperature range for the amorphisation of Scottish sediments is between $600{ }^{\circ} \mathrm{C}$ and $900{ }^{\circ} \mathrm{C}$, with an optimum of $750{ }^{\circ} \mathrm{C}$ for increased pozzolanic activity without additional $\mathrm{CO}_{2}$ emissions.

- The evolution of the compressive strength of mortars has shown a linear increase in compressive strength for 90 days for the different types of mortars based on partial substitution of cement by slag and calcined sediments. The best compressive strengths were observed in mortars composed of 50\% cement, $40 \%$ slag and $10 \%$ calcined sediment (CSS10\%) and this occurs after 90 days.

- The porosity of mortars based on partial substitution by slag and calcined sediments is greater than that of a mortar without addition at an early age. However, in the long term these substituted mortars developed a more refined pore size distribution, particularly for mortars composed of 50\% cement, $40 \%$ slag and 10\% calcined sediment (CSS10\%) and this occurs after 90 days.

- The substitution of calcined sediment and slag in mortar can significantly reduce leachability of elements and can help material to meet the thresholds of the solid waste classification (FR) or waste acceptance criteria (UK), while calcination itself will 
valorise most the organic contaminants found in sediments such as fuel residues or PAHs.

- The microscopic observation of the mortar with slag (CS) and mortar with slag and calcined sediment with a substitution rate of $10 \%$ (CSS10\%) demonstrated the development of a denser structure, which can significantly reduce porosity.

- Finally, it can be concluded that the addition of calcined sediments from Scotland can produce an artificial pozzolan character. If they are used to replace Portland cement, the replacement can save significant amounts of energy and can reduce greenhouse gas emissions. However, these trade-offs may be warranted by improved technical performance and the wider societal benefits of waste avoidance in the circular economy.

Author Contributions: Conceptualization, R.H.S., W.M., M.B. and R.L.; methodology, R.H.S., W.M. and M.B.; validation, R.H.S., W.M., M.B.,R.L., K.T., A.Z. and N.-E.A.; formal analysis, R.H.S.; investigation, R.H.S.; resources, M.B. and N.-E.A.; writing—original draft preparation, R.H.S.; writing-review \& editing, R.H.S., W.M. and R.L.; visualization, R.H.S. and W.M.; super-vision, R.H.S., W.M., M.B., R.L., K.T., A.Z. and N.-E.A.; project administration, M.B. and N.-E.A.; funding acquisition, M.B. and N.-E.A.; All authors have read and agreed to the published version of the manuscript.

Funding: This research was funded by the Interreg North-West Europe Programme to the SURICATES project and all partners.

Institutional Review Board Statement: Not applicable.

Informed Consent Statement: Not applicable.

Data Availability Statement: The data presented in this study are available on request from the corresponding author.

Acknowledgments: The author gratefully acknowledges the generous financial support from the European Regional Development Fund provided by the Interreg North-West Europe Programme to the SURICATES project and all partners. The authors would also like to thank the collaborators of the Scotish Canal and, in particular, Ignas Jakstys and Alasdair Hamilton.

Conflicts of Interest: The authors declare no conflict of interest.

\section{References}

1. Zacco, A.; Gianoncelli, A.; Ardesi, R.; Sacrato, S.; Guerini, L.; Bontempi, E.; Tomasoni, G.; Alberti, M.; Depero, L.E. Use of Colloidal Silica to Obtain a New Inert from Municipal Solid Waste Incinerator (MSWI) Fly Ash: First Results about Reuse. Clean Technol. Environ. Policy 2012, 14, 291-297. [CrossRef]

2. Amar, M.; Benzerzour, M.; Safhi, A.E.M.; Abriak, N.-E. Durability of a Cementitious Matrix Based on Treated Sediments. Case Stud. Constr. Mater. 2018, 8, 258-276. [CrossRef]

3. San Nicolas, R. Approche Performantielle Des Bétons Avec Métakaolins Obtenus Par Calcination Flash. Ph.D. Thesis, Université de Toulouse III-Paul Sabatier, Toulouse, France, 2011.

4. Rodríguez, O.; Kacimi, L.; López-Delgado, A.; Frías, M.; Guerrero, A. Characterization of Algerian Reservoir Sludges for Use as Active Additions in Cement: New Pozzolans for Eco-Cement Manufacture. Constr. Build. Mater. 2013, 40, 275-279. [CrossRef]

5. Millrath, K.; Kozlova, S.; Shimanovich, S.; Meyer, C. Beneficial Use of Dredge Material; 610 SW Mudd Building: New York, NY, USA, 2001; p. 10027.

6. Xu, Y.; Yan, C.; Xu, B.; Ruan, X.; Wei, Z. The Use of Urban River Sediments as a Primary Raw Material in the Production of Highly Insulating Brick. Ceram. Int. 2014, 40, 8833-8840. [CrossRef]

7. Dang, T.A.; Kamali-Bernard, S.; Prince, W.A. Design of New Blended Cement Based on Marine Dredged Sediment. Constr. Build. Mater. 2013, 41, 602-611. [CrossRef]

8. Siham, K.; Fabrice, B.; Edine, A.N.; Patrick, D. Marine Dredged Sediments as New Materials Resource for Road Construction. Waste Manag. 2008, 28, 919-928. [CrossRef]

9. Dubois, V.; Abriak, N.E.; Zentar, R.; Ballivy, G. The Use of Marine Sediments as a Pavement Base Material. Waste Manag. 2009, 29, 774-782. [CrossRef]

10. Chidiac, S.E.; Panesar, D.K. Evolution of Mechanical Properties of Concrete Containing Ground Granulated Blast Furnace Slag and Effects on the Scaling Resistance Test at 28 days. Cem. Concr. Compos. 2008, 30, 63-71. [CrossRef]

11. Hadj Sadok, A.; Courard, L. Chloride Diffusion and Oxygen Permeability of Mortars with Low Active Blast Furnace Slag. Constr. Build. Mater. 2018, 181, 319-324. [CrossRef] 
12. Bougara, A.; Lynsdale, C.; Milestone, N.B. The Influence of Slag Properties, Mix Parameters and Curing Temperature on Hydration and Strength Development of Slag/Cement Blends. Constr. Build. Mater. 2018, 187, 339-347. [CrossRef]

13. Bougara, A.; Lynsdale, C.; Ezziane, K. Activation of Algerian Slag in Mortars. Constr. Build. Mater. 2009, 23, 542-547. [CrossRef]

14. Deboucha, W.; Leklou, N.; Khelidj, A. Combination Effect of Limestone Filler and Slag on Hydration Reactions in Ternary Cements. Eur. J. Environ. Civ. Eng. 2020, 1-16. [CrossRef]

15. Snellings, R.; Cizer, Ö.; Horckmans, L.; Durdziński, P.T.; Dierckx, P.; Nielsen, P.; Van Balen, K.; Vandewalle, L. Properties and Pozzolanic Reactivity of Flash Calcined Dredging Sediments. Appl. Clay Sci. 2016, 129, 35-39. [CrossRef]

16. Misko, P.; Gros Demange, D.; Bougio, Y. Guide Pour la Gestion Durable des Deblais de Dragage des Deblais de Dragege Portuaires Contaminés en France; Centre D'études Techniques Maritimes et Fluviales (CETMEF): Beauvais, Feance, 2008 ; p. 61.

17. Gastaldini, A.L.G.; Hengen, M.F.; Gastaldini, M.C.C.; do Amaral, F.D.; Antolini, M.B.; Coletto, T. The Use of Water Treatment Plant Sludge Ash as a Mineral Addition. Constr. Build. Mater. 2015, 94, 513-520. [CrossRef]

18. Benkaddour, M.; Aoual, F.K.; Semcha, A. Durabilité des mortiers à base de pouzzolane naturelle et de pouzzolane artificielle. Rev. Nat. Technol. 2009, 1, 63-73.

19. Rozière, E.; Samara, M.; Loukili, A.; Damidot, D. Valorisation of Sediments in Self-Consolidating Concrete: Mix-Design and Microstructure. Constr. Build. Mater. 2015, 81, 1-10. [CrossRef]

20. Gastaldini, A.L.G.; da Silva, M.P.; Zamberlan, F.B.; Mostardeiro Neto, C.Z. Total Shrinkage, Chloride Penetration, and Compressive Strength of Concretes That Contain Clear-Colored Rice Husk Ash. Constr. Build. Mater. 2014, 54, 369-377. [CrossRef]

21. Tironi, A.; Trezza, M.A.; Scian, A.N.; Irassar, E.F. Assessment of Pozzolanic Activity of Different Calcined Clays. Cem. Concr. Compos. 2013, 37, 319-327. [CrossRef]

22. Aboulayt, A.; Jaafri, R.; Samouh, H.; Cherki El Idrissi, A.; Roziere, E.; Moussa, R.; Loukili, A. Stability of a New Geopolymer Grout: Rheological and Mechanical Performances of Metakaolin-Fly Ash Binary Mixtures. Constr. Build. Mater. 2018, 181, 420-436. [CrossRef]

23. Lynn, C.J.; Dhir, R.K.; Ghataora, G.S.; West, R.P. Sewage Sludge Ash Characteristics and Potential for Use in Concrete. Constr. Build. Mater. 2015, 98, 767-779. [CrossRef]

24. Walker, R.; Pavía, S. Physical Properties and Reactivity of Pozzolans, and Their Influence on the Properties of Lime-Pozzolan Pastes. Mater. Struct. 2011, 44, 1139-1150. [CrossRef]

25. Dodson, V.H. Concrete Admixtures; Springer: Berlin/Heidelberg, Germany, 2013; ISBN 978-1-4757-4845-1.

26. Aoual-Benslafa, F.K.; Kerdal, D.; Ameur, M.; Mekerta, B.; Semcha, A. Durability of Mortars Made with Dredged Sediments. Procedia Eng. 2015, 118, 240-250. [CrossRef]

27. Safer, O.; Belas, N.; Belaribi, O.; Belguesmia, K.; Bouhamou, N.-E.; Mebrouki, A. Valorization of Dredged Sediments as a Component of Vibrated Concrete: Durability of These Concretes against Sulfuric Acid Attack. Int. J. Concr. Struct. Mater. 2018, 12, 44. [CrossRef]

28. Cyr, M.; Lawrence, P.; Ringot, E. Mineral Admixtures in Mortars: Quantification of the Physical Effects of Inert Materials on Short-Term Hydration. Cem. Concr. Res. 2005, 35, 719-730. [CrossRef]

29. Lawrence, P.; Cyr, M.; Ringot, E. Mineral Admixtures in Mortars Effect of Type, Amount and Fineness of Fine Constituents on Compressive Strength. Cem. Concr. Res. 2005, 35, 1092-1105. [CrossRef]

30. Lim, Y.C.; Lin, S.-K.; Ju, Y.-R.; Wu, C.-H.; Lin, Y.-L.; Chen, C.-W.; Dong, C.-D. Reutilization of Dredged Harbor Sediment and Steel Slag by Sintering as Lightweight Aggregate. Process Saf. Environ. Prot. 2019, 126, 287-296. [CrossRef]

31. Wei, Y.-L.; Lin, C.-Y.; Cheng, S.-H.; Wang, H.P. Recycling Steel-Manufacturing Slag and Harbor Sediment into Construction Materials. J. Hazard. Mater. 2014, 265, 253-260. [CrossRef]

32. Slama, A.B.; Feki, N.; Levacher, D.; Zairi, M. Valorization of Harbor Dredged Sediment Activated with Blast Furnace Slag in Road Layers. Int. J. Sediment Res. 2020. [CrossRef]

33. SURICATES—Sediment Uses as Resources in Circular and Territorial Economies. Available online: https://www.nweurope. eu/projects/project-search/suricates-sediment-uses-as-resources-in-circular-and-territorial-economies/ (accessed on 26 December 2020).

34. Benzerzour, M.; Maherzi, W.; Amar, M.A.; Abriak, N.-E.; Damidot, D. Formulation of Mortars Based on Thermally Treated Sediments. J. Mater. Cycles Waste Manag. 2018, 20, 592-603. [CrossRef]

35. Semcha, A. Valorisation Des Sédiments de Dragage: Applications Dans Le BTP, Cas Du Barrage de Fergoug. Ph.D. Thesis, Université de Reims Champagne-Ardenne, Reims, France, 2006.

36. AFNOR NF EN 197-1, N.E. 197-1-A. Cement_Part 1: Composition, Specifications and Conformity Criteria for Common Cements-Ciment; French Standard Institute: Paris, France, 2012.

37. AFNOR NF EN 196-1, N.E. 196-1 Methods of Testing Cement_Part 1: Determination of Strength; French Standard Institute: Paris, France, 2016.

38. Hadj Sadok, R. Analyse du Cycle de vie des Sédiments de Dragage. Ph.D. Thesis, Université Abdelhamid Ibn Badis De Mostaganem, Mostaganem, Algeria, 2019.

39. AFNOR NF EN 196-9, N.E. 196-9 Methods of Testing Cement-Part 9: Heat of Hydration-Semi-Adiabatic Method; French Standard Institute: Paris, France, 2010.

40. AFNOR NF EN 1097-7, N.E. 1097-7 Tests for Mechanical and Physical Properties of Aggregates_Part 7: Determination of the Particle Density of Filler-Pyknometer Method; French Standard Institute: Paris, France, 2008. 
41. AFNOR NF P94-410-3, N.P.-410-3. Rock—Tests for Physical Properties of Rock-Part 3: Determination of Porosity—Roches; French Standard Institute: Paris, France, 2001.

42. Benzerzour, M.; Amar, M.; Abriak, N.-E. New Experimental Approach of the Reuse of Dredged Sediments in a Cement Matrix by Physical and Heat Treatment. Constr. Build. Mater. 2017, 140, 432-444. [CrossRef]

43. Maherzi, W.; Ennahal, I.; Benzerzour, M.; Mammindy-Pajany, Y.; Abriak, N.-E. Study of the Polymer Mortar Based on Dredged Sediments and Epoxy Resin: Effect of the Sediments on the Behavior of the Polymer Mortar. Powder Technol. 2020, 361, 968-982. [CrossRef]

44. Nielsen, L.F. Strength Development in Hardened Cement Paste: Examination of Some Empirical Equations. Mater. Struct. 1993, 26, 255-260. [CrossRef]

45. AFNOR NF EN 12457-2, N.E. 12457-2 Characterization of Waste-Leaching-Compliance Test for Leaching of Granular Waste Materials and Sludges-Part 2: One Stage Batch Test at a Liquid to Solid Ratio of $10 \mathrm{l} / \mathrm{Kg}$ for Materials with Particle Size below $4 \mathrm{Mm}$ (without or with Size Reduction)—Caractérisation Des Déchets; French Standard Institute: Paris, France, 2002.

46. Alujas, A.; Fernández, R.; Quintana, R.; Scrivener, K.L.; Martirena, F. Pozzolanic Reactivity of Low Grade Kaolinitic Clays: Influence of Calcination Temperature and Impact of Calcination Products on OPC Hydration. Appl. Clay Sci. 2015, 108, 94-101. [CrossRef]

47. Chikouche, M.A.; Ghorbel, E.; Bibi, M. The Possibility of Using Dredging Sludge in Manufacturing Cements: Optimization of Heat Treatment Cycle and Ratio Replacement. Constr. Build. Mater. 2016, 106, 330-341. [CrossRef]

48. Mohammed, S. Processing, Effect and Reactivity Assessment of Artificial Pozzolans Obtained from Clays and Clay Wastes: A Review. Constr. Build. Mater. 2017, 140, 10-19. [CrossRef]

49. Taylor-Lange, S.C.; Lamon, E.L.; Riding, K.A.; Juenger, M.C.G. Calcined Kaolinite-Bentonite Clay Blends as Supplementary Cementitious Materials. Appl. Clay Sci. 2015, 108, 84-93. [CrossRef]

50. Gridi-Bennadji, F.; Beneu, B.; Laval, J.P.; Blanchart, P. Structural Transformations of Muscovite at High Temperature by X-ray and Neutron Diffraction. Appl. Clay Sci. 2008, 38, 259-267. [CrossRef]

51. Janotka, I.; Puertas, F.; Palacios, M.; Kuliffayová, M.; Varga, C. Metakaolin Sand-Blended-Cement Pastes: Rheology, Hydration Process and Mechanical Properties. Constr. Build. Mater. 2010, 24, 791-802. [CrossRef]

52. Aasly, K.; Malvik, T.; Myrhaug, E.H. Advanced Methods to Characterize Thermal Properties of Quartz. Infacon Xi 2007, 1, 381-392.

53. Laidani, Z.E.-A.; Benabed, B.; Abousnina, R.; Gueddouda, M.K.; Khatib, M.J. Potential Pozzolanicity of Algerian Calcined Bentonite Used as Cement Replacement: Optimisation of Calcination Temperature and Effect on Strength of Self-Compacting Mortars. Eur. J. Environ. Civ. Eng. 2020, 1-23. [CrossRef]

54. Jiang, T.; Li, G.; Qiu, G.; Fan, X.; Huang, Z. Thermal Activation and Alkali Dissolution of Silicon from Illite. Appl. Clay Sci. 2008, 40,81-89. [CrossRef]

55. Karunadasa, K.S.P.; Manoratne, C.H.; Pitawala, H.M.T.G.A.; Rajapakse, R.M.G. Thermal Decomposition of Calcium Carbonate (Calcite Polymorph) as Examined by in-Situ High-Temperature X-ray Powder Diffraction. J. Phys. Chem. Solids 2019, 134, 21-28. [CrossRef]

56. Laidani, Z.E.-A.; Benabed, B.; Abousnina, R.; Gueddouda, M.K.; Kadri, E.-H. Experimental Investigation on Effects of Calcined Bentonite on Fresh, Strength and Durability Properties of Sustainable Self-Compacting Concrete. Constr. Build. Mater. 2020, 230, 117062. [CrossRef]

57. Al-Rawas, A.A.; Wahid Hago, A.; Corcoran, T.C.; Al-Ghafri, K.M. Properties of Omani Artificial Pozzolana (Sarooj). Appl. Clay Sci. 1998, 13, 275-292. [CrossRef]

58. Danner, T.; Norden, G.; Justnes, H. Calcareous Smectite Clay as a Pozzolanic Alternative to Kaolin. Eur. J. Environ. Civ. Eng. 2019, 1-18. [CrossRef]

59. Zhou, Y.; Li, J.; Lu, J.; Cheeseman, C.; Poon, C.S. Sewage Sludge Ash: A Comparative Evaluation with Fly Ash for Potential Use as Lime-Pozzolan Binders. Constr. Build. Mater. 2020, 242, 118160. [CrossRef]

60. Zajac, M.; Skocek, J.; Durdzinski, P.; Bullerjahn, F.; Skibsted, J.; Ben Haha, M. Effect of Carbonated Cement Paste on Composite Cement Hydration and Performance. Cem. Concr. Res. 2020, 134, 106090. [CrossRef]

61. Bouarroudj, M.E.; Rémond, S.; Bulteel, D.; Potier, G.; Michel, F.; Zhao, Z.; Courard, L. Use of Grinded Hardened Cement Pastes as Mineral Addition for Mortars. J. Build. Eng. 2020, 34, 101863. [CrossRef]

62. Du, H.; Pang, S.D. High-Performance Concrete Incorporating Calcined Kaolin Clay and Limestone as Cement Substitute. Constr. Build. Mater. 2020, 264, 120152. [CrossRef]

63. el Mahdi Safhi, A.; Rivard, P.; Yahia, A.; Benzerzour, M.; Khayat, K.H. Valorization of Dredged Sediments in Self-Consolidating Concrete: Fresh, Hardened, and Microstructural Properties. J. Clean. Prod. 2020, 263, 121472. [CrossRef]

64. Dang, J.; Du, H.; Pang, S.D. Hydration, Strength and Microstructure Evaluation of Eco-Friendly Mortar Containing Waste Marine Clay. J. Clean. Prod. 2020, 272, 122784. [CrossRef]

65. Roy, D.M.; Ldorn, G.M. Hydration, Structure, and Properties of Blast Furnace Slag Cements, Mortars, and Concrete. J. Proc. 1982, 79, 444-457. [CrossRef]

66. Hogan, F.J.; Meusel, J.W. Evaluation for Durability and Strength Development of a Ground Granulated Blast Furnace Slag. Cem. Concr. Aggreg. 1981, 3, 40-52. [CrossRef]

67. Bougara, A.; Lynsdale, C.; Milestone, N.B. Reactivity and Performance of Blastfurnace Slags of Differing Origin. Cem. Concr. Compos. 2010, 32, 319-324. [CrossRef] 
68. Hadjsadok, A.; Kenai, S.; Courard, L.; Michel, F.; Khatib, J. Durability of Mortar and Concretes Containing Slag with Low Hydraulic Activity. Cem. Concr. Compos. 2012, 34, 671-677. [CrossRef]

69. el Mahdi Safhi, A.; Benzerzour, M.; Rivard, P.; Abriak, N.-E. Feasibility of Using Marine Sediments in SCC Pastes as Supplementary Cementitious Materials. Powder Technol. 2019, 344, 730-740. [CrossRef]

70. Hadj Sadok, R.; Belas, N.; Tahlaiti, M.; Mazouzi, R. Reusing Calcined Sediments from Chorfa II Dam as Partial Replacement of Cement for Sustainable Mortar Production. J. Build. Eng. 2021, 40, 102273. [CrossRef]

71. Cheng, A.; Huang, R.; Wu, J.-K.; Chen, C.-H. Influence of GGBS on Durability and Corrosion Behavior of Reinforced Concrete. Mater. Chem. Phys. 2005, 93, 404-411. [CrossRef]

72. Hadj Sadok, A. Effect of the Microstructure of Mortars with Low Hydraulicity Slag on Their Behavior in Aggressive Environments. MATEC Web Conf. 2018, 149, 01025. [CrossRef]

73. Hadj-sadok, A.; Kenai, S.; Courard, L.; Darimont, A. Microstructure and Durability of Mortars Modified with Medium Active Blast Furnace Slag. Constr. Build. Mater. 2011, 25, 1018-1025. [CrossRef]

74. Dubois, V. Etude Du Comportement Physico-Mécanique et Caractérisation Environnementale Des Sédiments Marins: Valorisation En Technique Routière. Ph.D. Thesis, Université d'Artois, Arras, France, 2006.

75. Thanh, T.N. Valorisation de Sédiments Marins et Fluviaux En Technique Routière; Université d'Artois: Arras, France, 2009.

76. Hadj Sadok, R.; Tahlaiti, M.; Belas, N.; Mazouzi, R. Environmental Life Cycle Assessment of Industrialization Process of Calcined Dredged Sediments. J. Mater. Eng. Struct. JMES 2019, 6, 25-37. 